\title{
Dual clathrin and adhesion signaling systems regulate growth factor receptor activation.
}

Marco A. Alfonzo-Mendez, Kem A. Sochacki, Marie-Paule Strub, Justin W. Taraska*

Biochemistry and Biophysics Center, National Heart, Lung, and Blood Institute, National Institutes of

Health, 50 South Drive, Building 50, Bethesda, MD 20892

*Corresponding author: justin.taraska@nih.gov

Key words: Flat Clathrin Lattices, EGFR, Src, $\beta 5$-integrin, Crosstalk, Phosphorylation, Electron

Microscopy, TIRF Microscopy.

\section{ABSTRACT}

11 The crosstalk between growth factor and adhesion receptors is key for cell growth and migration. In

12 pathological settings, these receptors are drivers of cancer. Yet, how growth and adhesion signals are

13 spatially organized and integrated is poorly understood. Here we use quantitative fluorescence and

14 electron microscopy to reveal a mechanism where flat clathrin lattices partition and activate growth

factor signals via a coordinated response that involves crosstalk between epidermal growth factor

receptor (EGFR) and the adhesion receptor $\beta 5$-integrin. We show that ligand-activated EGFR, Grb2, Src,

17 and $\beta 5$-integrin are captured by clathrin coated-structures at the plasma membrane. Clathrin structures

dramatically grow in response to ligand activation into large flat plaques and provide a signaling

21 reveals a reciprocal regulation of clathrin lattices and two different receptor systems to enhance cell 
22 growth factor signaling. These findings have broad implications for the control of growth factor

23 receptors, mechanotransduction, and endocytosis.

\section{INTRODUCTION}

27 membrane (PM) receptors of which the receptor tyrosine kinases (RTKs) are one of the major superfamilies. RTKs are ubiquitous integral membrane proteins in eukaryotes that perform numerous actions including the regulation of cell proliferation, differentiation, survival and migration ${ }^{1}$. Epidermal growth factor receptor (EGFR) is one of the most widely studied members of the RTK superfamily, which regulates epithelial tissue development and homeostasis. In lung, breast, and

32 head and neck cancers, EGFR is a driver of tumorigenesis and is a major target for therapy ${ }^{2,3}$. EGFR

33 spans the membrane and contains a ligand-interacting domain facing the extracellular space and a

34 tyrosine kinase region in the cytoplasm ${ }^{4}$. The binding of EGFR to epidermal growth factor (EGF)

35 triggers receptor dimerization and cross-phosphorylation of tyrosine residues within its cytosolic

36 domain ${ }^{5,6}$. This provides docking sites for the recruitment of scaffold proteins including Grb2 and the

37 activation of downstream tyrosine kinases such as $\mathrm{Src}^{7-9}$. The EGFR pathway can be activated either

38 directly by its cognate ligands or through transactivation by other signaling proteins including

39 integrins $^{10,11}$.

40 Integrins are adhesion molecules that are responsible for cell-cell and cell-matrix interactions, and

41 relay mechanical signals bidirectionally between the extracellular space and the cytoplasm ${ }^{12}$. In this

42 way, integrins sense the local environment and control tissue rigidity, cell growth, and movement ${ }^{13}$.

43 Dysregulation of integrin signaling contributes to cancer and metastasis ${ }^{14}$. Integrins are thought to be

44 heterodimers of $\alpha$ and $\beta$ subunits, each containing a large multidomain extracellular region (>700 
residues) for ligand biding, a single transmembrane helix, and a short cytoplasmic tail (13-70 residues $)^{15}$. $\beta$-integrin cytoplasmic tails lack enzymatic activity. Instead, they harbor distinct

47 regulatory sequences including two NPxY motifs (Asn-Pro-x-Tyr) that can be phosphorylated ${ }^{16}$. NPxY motifs have a high affinity for phosphotyrosine binding domain proteins ${ }^{17}$. This allows them to bind to signaling partners including clathrin-mediated endocytosis (CME) accessory proteins ${ }^{18,19}$. While these proteins are known to interact generally, how they are spatially organized at the PM to control

51 signaling and crosstalk is unclear.

52 EGFR and integrins can be regulated through CME - the main pathway used by eukaryotic cells to

53 internalize receptors into the cytoplasm ${ }^{20,21}$. During $\mathrm{CME}$, clathrin and adaptors assemble to bend the

54 membrane into $\Omega$-shaped pits ${ }^{22,23}$. Scission of clathrin-coated pits (CCPs) from the PM yields closed

55 spherical vesicles with an average diameter of $\sim 100 \mathrm{~nm}^{24}$. Besides CCPs, cells exhibit a subset of clathrin coats known as flat clathrin lattices (FCLs) or plaques ${ }^{25,26}$. In contrast to CCPs, FCLs are long-lived on the

57 PM and display a variety of two-dimensional shapes ${ }^{27,28}$. FCLs are abundant in myocytes and can bind

58 cortical actin during muscle formation and function ${ }^{29,30}$. FCLs are also important for the adhesion between osteoclasts and bone ${ }^{31,32}$. During cell communication, different types of receptors including EGFR are clustered at FCLs ${ }^{33}$. Additionally, FCLs are enriched with $\beta 5$-integrin ${ }^{34-36}$. Yet, it is unknown how

61 flat clathrin lattices are regulated and their general functions are still unclear.

62 Here, we identified an EGFR/ $\beta 5$-integrin/Src signaling axis that regulates flat clathrin lattice biogenesis

63 during growth factor stimulation. Using a combination of quantitative fluorescence and electron

64 microscopy, we showed that EGF triggers large ultrastructural changes in the membrane of human

65 squamous ( $\mathrm{HSC} 3$ ) cells. These changes include the generation and expansion of large FCLs and

66 required EGFR interactions with EGF as well as Src kinase and $\beta 5$-integrin. Agonist stimulation leads to

67 persistent recruitment of EGFR, Grb2, and $\beta 5$-integrin into clathrin structures, and a corresponding loss 
of Src kinase. We provide evidence of $\beta 5$-integrin phosphorylation mediated by Src that regulates this signaling system. These data reveal a mutual regulation of FCLs and two different receptor systems: EGFR and $\beta 5$ integrin. Thus, an EGFR/ $\beta 5$-integrin/Src axis contributes to the biogenesis of FCLs, which in turn act as dynamic signaling platforms to partition and enhance growth factor signaling at the PM of human cells.

\section{RESULTS}

\section{EGF triggers changes in the ultrastructure of clathrin lattices}

First, we tracked the ultrastructure of clathrin at the PM during growth factor stimulation. To accomplish this, we used genome-edited HSC3 cells endogenously expressing EGFR tagged with GFP, an established model to study EGFR endocytosis and human EGFR-dependent head and neck carcinoma ${ }^{37-39}$. We treated HSC3 cells with vehicle (Ctrl) or EGF for 2, 5, 15, 30 and 60 min. Then, we mechanically unroofed cells to directly visualized clathrin at the cytoplasmic face of the PM using platinum replica transmission electron microscopy $(\mathrm{PREM})^{40}$. In these images, we measured the structure and distribution of clathrin coated structures (CCSs) across the PM of control and EGF stimulated cells. Remarkably, CCSs were 4.6fold more abundant in cells stimulated with EGF for 15 min (Fig. 1a-d and Sup. Fig.1).

PREM allowed us to segment distinct CCSs based on their curvature into three subclasses: 1) flat clathrin lattices (FCLs), where no curvature is evident (shown in green); 2) dome, curved but the clathrin edge is visible (blue); and 3) sphere, highly curved and edge is not observable (magenta) (Fig. 1a-d) ${ }^{41}$.

Representative segmentation masks illustrate the densities of diverse CCSs densities at different time points of EGF stimulation (Fig. 1e). We compared the differences in densities by quantifying the membrane occupation of all CCSs (Sup. Fig. 1) and individual subclasses (Fig. 1f-h). All CCSs in control cells occupied $0.84 \pm 0.2 \%$ membrane area and markedly increased $2.5-, 4.6$ - and 5-fold after EGF 
91 stimulation for 5, 15, and 30 min, respectively. The area of all CCSs decreased to near baseline levels

92 after $60 \mathrm{~min}(0.67 \pm 0.33 \%)$ (Sup. Fig. 1). Notably, membrane area occupation of FCLs followed a similar

93 time course to all CCSs classes, with a peak at 15 and 30 min post-EGF $(3.2 \pm 0.58 \%, 6.5$-fold; $3.3 \pm 1.92 \%$, 6.7-fold), reaching near-baseline levels at $60 \mathrm{~min}(0.5 \pm 0.22 \%)$ (Fig. 1f). In contrast, the mean membrane occupation of domed and spherical clathrin structures remained below $1 \%$ with no significant differences across the times tested (Fig. 1g-h). Thus, EGF specifically increased the total area occupied by FCLs at the plasma membrane.

FCLs were considerably bigger after EGF treatment (Fig. 1a-d). The distribution range of the size of ultrastructure of FCLs and the temporal response to EGF at the plasma membrane.

\section{EGFR, Src and $\beta 5$-integrin are required for flat clathrin lattice formation}

107 signaling can regulate $\mathrm{FCL}$ biogenesis during growth factor stimulation. To identify the possible members 108 of the EGFR signaling pathway involved in this process, we performed a pharmacological screen (Fig. 2g). 109 We first targeted EGFR using gefitinib (Gefi), a drug that blocks receptor activity by binding to the ATPpocket in the tyrosine kinase domain ${ }^{42}$. PREM of HSC3 cells preincubated with gefitinib followed by EGF

111 treatment showed a percentage of FCLs membrane area occupation (Gefi+EGF=0.66 $\pm 0.13 \%$ ) similar to 112 control cells (Ctrl= $0.48 \pm 0.11 \%$ ) (Fig. $2 \mathrm{a}-\mathrm{c}$ ). Thus, gefitinib decreased the effect of EGF on FCL formation 113 by 4.8-fold (Fig. 2h). We then aimed to evaluate the role of the tyrosine kinase Src for two main reasons. 
First, Src is a master effector immediately downstream of EGFR. And second, Src has been reported to

115 directly phosphorylate proteins key to the endocytic machinery ${ }^{43-45}$. We used PP2, a specific Src family kinase inhibitor ${ }^{46}$, and then challenged the cells with EGF. We observed a 4.1-fold decrease in FCLs occupation compared to EGF alone, and similar as compared to control cells (PP2+EGF= $0.77 \pm 0.24 \%$ )

118 (Fig. 2d). We also targeted the $\beta 5$-integrin, a known component of $\mathrm{FCLs}^{19}{ }^{34}$. We treated cells with consistent with the other two drugs tested (CTA+EGF= 1.48. $\pm 0.73 \%)$ (Fig. 2e). Representative segmentation masks illustrate the diversity of CCSs in the presence of the three blockers (Fig. 2f). The

124 significantly affect the percentage of membrane area occupied or the size of domed and spherical 125 clathrin structures, in the presence or absence of EGF (Sup. Fig.3). Overall, these data indicated that 126 activated EGFR, the downstream tyrosine kinase Src, and $\beta 5$-integrin are all required for the EGF127 induced biogenesis of FCLs. 
137 fluorescent signal across the bottom PM in control cells ( $C=0.15 \pm 0.06)$. EGF stimulation caused the

138 appearance of pronounced EGFR clusters and a 2.4 -fold increase in its correlation with clathrin

$139(\mathrm{C}=0.3 \pm 0.15)$ (see white in overlay). We observed a similar increase in wild type (WT) HSC3 cells co-

140 transfected with EGFR-GFP and mScarlet-CLCa stimulated with EGF (Sup. Fig. 5). We then imaged control

141 cells expressing Src-GFP that showed diffuse florescence similar to EGFR (Fig. 3a). Likewise, the Src signal

142 correlated with clathrin $(C=0.41 \pm 0.1)$, but decreased 2.2 -fold in the presence of EGF $(C=0.18 \pm 0.1)$ (Fig.

$1433 b)$. Interestingly, the $\beta 5$-integrin signal appeared as discreet puncta that markedly correlated with

144 clathrin in both control $(C=0.79 \pm 0.11)$ and EGF treated cells ( $C=0.76 \pm 0.07)$ (Fig. 3a-b). Thus, EGFR, Src

145 and, $\beta 5$-integrin differentially correlate with clathrin. To further confirm this, we measured the EGFR

146 and Src signal using $\beta 5$-integrin as a reference. Similarly, stimulation increased the $\beta 5$-integrin

147 correlation with EGFR, but decreased correlation with Src (Sup. Fig. 6). Of note, we tested other

148 members of the $\beta$-integrin subfamily including $\beta 1, \beta 3$, and $\beta 6$ as well as $\alpha \mathrm{V}$, the most frequent partner

149 of $\beta 5$-integrin. However, the correlation values were 2 - to 4 -fold smaller when compared to the $\beta 5$ -

150 integrin correlation with clathrin (Sup. Fig. 7). Altogether, these data support the idea that EGF leads to

151 a persistent recruitment of EGFR and $\beta 5$-integrin into CCSs with a concurrent loss of Src.

EGFR and $\beta 5$-integrin are connected through Src-mediated phosphorylation

153 Next we assessed the biochemical connection between EGFR, Src and $\beta 5$-integrin. EGF binding elicits

154 EGFR dimerization leading to Src tyrosine kinase activation ${ }^{49} \cdot \beta 5$-integrin cytoplasmic domain has three

155 tyrosine residues (Y766, Y774 and Y796) that are highly conserved among their orthologues and

156 paralogues (Sup. Fig. 8). In silico analysis suggested Src, among other kinases, has a substantial likelihood

157 of catalyzing phosphorylation at all tyrosines of the $\beta 5$-integrin cytoplasmic domain (Sup. Fig 8 ). We

158 therefore hypothesized that these proteins form a signaling loop that can regulate clathrin remodeling

159 through phosphorylation. To support this hypothesis, we used a luciferase-coupled system to measure 
the phosphorylation of synthetic peptides corresponding to the $\beta 5$-integrin cytoplasmic domain (Fig.

4a). We detected a 13.6-fold increase in the phosphorylation of the WT peptide in the presence of Src,

was reduced when we tested the non-phosphorylatable peptide 3Y-F. As a positive control, we

164 incubated a peptide corresponding to amino acids $6-20$ of $\mathrm{p} 34^{\text {cdc2 }}$, a well characterized Src substrate ${ }^{50}$, in

the presence of purified and active Src, and we found an incremented phosphorylation. While $\beta 5$ -

integrin has been reported to be phosphorylated by PAK4 at $\mathrm{S} 759$ and $\mathrm{S762}{ }^{51}$, we did not detect

data indicate that the intracellular domain of $\beta 5$-integrin is a bona fide Src substrate in vitro.

171 phosphorylatable (3Y-F), phosphomimetic (3Y-E), or PAK targeted (2S-A) mutants (Fig. 4a). We tested

172 this mutants using two-color TIRFM as previously described. In control cells, we observed that the

173 fluorescent signal of either WT, 3Y-F, 3Y-E or 2S-A mutants appeared as diffraction-limited punctate that

174 highly correlated with clathrin ( $C=0.79 \pm 0.1,0.81 \pm 0.11,0.76 \pm 0.08,0.82 \pm 0.09$, respectively) (Fig. $4 c-d)$. In

175 contrast, the $\Delta C$ mutant exhibited a diffuse fluorescence across the membrane and a greatly decreased

176 correlation with clathrin $(C=0.41 \pm 0.08)$. In cells stimulated with $E G F$, we observed that the WT $\beta 5$ -

177 integrin strongly correlated with clathrin ( $C=0.84 \pm 0.05)$ (Fig. 4 and Fig. $5 c-d)$. This spatial correlation was

178 abolished in the $\Delta C(C=0.18 \pm 0.12)$ and the $3 Y-F$ mutant $(C=0.46 \pm 0.21)$. By contrast, the correlation with

179 clathrin persisted in the $3 Y-E(C=0.76 \pm 0.04)$ and the $2 S-A$ mutants $(C=0.8 \pm 0.07)$. Thus, $\beta 5$-integrin

180 requires tyrosine phosphorylation to spatially correlate with clathrin. Moreover, these experiments

181 suggest that crosstalk between EGFR and $\beta 5$-integrin mediated by Src takes place at CCSs. 
Finally, we hypothesized that FCLs mediate EGFR membrane-associated signal transduction by

regulating the distribution of active receptors and downstream interactors in both space and time. Using

TIRFM, we visualized the presence of active EGFR at the PM by immunolabeling endogenous phosphor-

Y1068 (P-EGFR), a well-established marker of EGFR activity (Fig. 5a). In stimulated cells, the correlation

187 of P-EGFR with clathrin increased 3.5-fold $(C=0.6 \pm 0.11)$ with respect to the control $(C=0.17 \pm 0.1)$.

with clathrin by $\sim 30 \%(C=0.41 \pm 0.14$ ) (Fig 5 b). A similar trend was observed when we measured the

fluorescence intensity of P-EGFR at the PM (Fig. 5c). Furthermore, we measured the fluorescence

intensity of the total EGFR-GFP signal (T-EGFR) at the PM as an indicator of receptor internalization. We

observed that EGF led to a $41.7 \%$ decrease of the T-EGFR, and CTA treatment further decreased

receptor at the PM (68.7\%) (Fig. 5d). We also examined the location of the downstream master scaffold

194 Grb2 in FCLs (Fig. 5e). While EGF caused an increase in both Grb2 correlation with clathrin and

recruitment of the adaptor to the PM, CTA blocked these effects (Fig. 5e-). Together these data suggest

that FCLs activate growth factor signals at the PM by delaying endocytosis of a population of active EGFR

197 along with key partner proteins such as Grb2. These events are mediated by the phosphorylationdependent cross talk between EGFR, integrins, and clathrin at the plasma membrane.

\section{DISCUSSION}

201 Crosstalk between signaling systems allows for biological processes to be integrated, responsive, and

202 adaptable $\mathrm{e}^{52}$. There is an emerging hypothesis that FCLs can act as signaling zones or adhesion sites at the

203 PM, filling unique roles outside of endocytosis. Here, we show that activated EGFR, Src, and $\beta$ 5-integrin

204 are coupled to a dramatic growth and maintenance of FCLs in human cells. These planar clathrin sites in 
factor and adhesion) are connected, clustered, and controlled at the nanoscale by endocytic proteins.

207 We propose that a reciprocal feedback loop operates where FCLs facilitate local crosstalk between

208 EGFR, $\beta$ 5-integrin, and other signaling proteins to create dynamic signaling hubs across the PM.

209 First, we observed clathrin using platinum replica electron microscopy to structurally distinguish flat

210 from curved clathrin structures. Surprisingly, EGFR activation resulted in a dramatic increase in FCLs size

211 and density. Other shapes of clathrin were unchanged. Blocking the receptor abolished these effects. Of

212 note, the structural changes we see follow a time course similar to the activation dynamics of

213 downstream kinases ${ }^{53}$, further supporting the direct connection between clathrin remodeling and cell

214 signaling. Our pharmacological screening linked the tyrosine kinase Src and the adhesion receptor $\beta 5$ -

215 integrin to FCL formation and EGFR activation. Historically, growth factor receptors and integrins have

216 been biochemically connected to Src in several ways ${ }^{10}$. Here, we show a new direct spatial connection.

217 We also found that FCLs are preloaded with a subpopulation of Src. This kinase was released from the

218 complex in response to EGF. In contrast, $\beta 5$-integrin is enriched in $\mathrm{FCLs}^{19,34,35}$, and we found that this

219 correlation with clathrin persisted in response to EGF. Thus, EGFR, Src and $\beta 5$-integrin are dynamically

220 coupled through FCLs to regulate EGF signaling.

221 We showed that this new pathway is controlled by phosphorylation. Specifically, in silico analysis and

222 biochemical assays indicated that the $\beta 5$-integrin intracellular domain is a Src substrate. Src activation

223 kinetics are fast and occur within 5 minutes $^{54}$. Thus, it is possible that at an early stage of clathrin

224 growth, Src phosphorylates targets and is then released. While our results point toward an early

225 phosphorylation event in $\beta 5$-integrin mediated by Src, it is also possible that Src continually cycles on

226 and off clathrin during receptor activation and plays a more extensive role in the process. Likewise, Src is

227 a promiscuous kinase and might phosphorylate additional substrates located on other PM structures

228 such as caveolae and focal adhesions $\mathrm{s}^{55,56}$. 
Second, we found that deletion of the $\beta 5$-integrin cytoplasmic domain and non-phosphorylatable mutations (3Y-F) block integrin association with clathrin. These effects were rescued by a phosphomimic mutant ( $3 Y-E)$, suggesting that tyrosine phosphorylation of $\beta 5$-integrin is a molecular switch in this process. Interestingly, the $\beta 5$-integrin cytoplasmic domain interacts with endocytic proteins including Eps15, ARH, and Numb ${ }^{19}$. Integrin cytoplasmic tails can also induce profound differences in the behavior of integrins ${ }^{57}$. Thus, we propose that a phosphorylation switch in $\beta 5$-integrin is the regulator for the orchestrated recruitment of the endocytic machinery to sites where FCLs form and grow. In this regard, the growth factor response is directly linked to the cellular adhesion system through activation of

237 endocytic proteins and controlled by phosphorylation.

238 A recent hypothesis proposes that long-lived FCLs arise from adhesive forces generated from integrins that physically prevent clathrin from curving-a process called frustrated endocytosis ${ }^{34} 27,58$. Interestingly, we observed the FCL formation and the enrichment of active EGFR and Grb2 peak after 15 min of stimulation with EGF (Fig. 1 and 5). At the same time, we detected a decrease in the overall signal

242 of EGFR at the PM. This decrease suggests that EGF triggers the internalization of a population of EGFR 243 into the cell. In parallel, some phosphorylated and active receptors remain at the PM in clathrin. By

244 preventing endocytosis of a subpopulation of EGFR, this clathrin/adhesion complex could prolong EGF 245 signaling at these sites. These domains might also act as diffusion traps for EGFR and other growth 246 factor receptors whose diffusion decreases after agonist stimulation ${ }^{59-62}$. Using fluorescence microscopy,

247 EGFR and other structurally diverse receptors have been reported to form long-lived complexes ${ }^{27,63-66}$. In 248 contrast, stimulation of LPA1 receptor has been shown to trigger the depolymerization of FCLs ${ }^{33}$. Thus, 249 different systems might activate or deactivate these structures to regulate their activity. How 250 endocytosis, adhesion, and receptor diffusion cooperate across the entire population of active receptors 251 to control signaling will be an important future area of study. 
252 Is this mechanism unique to EGFR? Many receptors including 7-transmembrane receptors and B cell

253 receptors trigger clathrin nucleation at the PM upon biding their ligands ${ }^{27,63-66}$. For the $\beta_{2}$-adrenergic

254 receptor, the increase in clathrin occurs with a delay in clathrin-coated vesicle maturation and no

255 differences in the overall rate of vesicle scission ${ }^{64}$. Our data revealed a similar increase in clathrin

256 nucleation during EGF stimulation, but the major changes to clathrin occurred specifically and

257 exclusively with a dramatic growth in FCLs. It is possible that other receptor cargos also stabilize flat

258 clathrin coats to act as nanoscale receptor signaling domains. Thus, FCLs could be generalized signaling

259 hubs at the PM. Future work is needed to test this hypothesis.

260 Growing evidence suggests that signaling systems are locally organized by organelles and cytoskeletal

261 structures. We propose that FCLs are a unique plasma membrane scaffold that dynamically capture and

262 organize receptors and signaling molecules in space and time through multivalent interactions at the

263 nanoscale. We suggest that crosstalk between EGFR and $\beta 5$-integrin through Src phosphorylation occurs

264 in FCLs and simultaneously regulates their biogenesis. Finally, because of the importance of

$265 \mathrm{EGFR} / \mathrm{Src} / \beta 5$-integrin in physiology, and the connection between dysregulation of this system and

266 cancer, FCLs likely play a broader role in coordinating the cellular responses to chemical and mechanical

267 stimuli. Understanding these pathways is key to understanding cellular functions in both health and

268 disease. Our data provide a new nanoscale signaling platform that dynamically organizes, coordinates,

269 and regulates this essential biology.

270 METHODS

271 Cell culture and transfection

272 Wild-type HSC-3 (human oral squamous carcinoma) cells were obtained from the JCRB Cell Bank

273 (JCRB0623). Genome-edited HSC-3 cells expressing endogenous EGFR-GFP were previously reported ${ }^{39}$

274 and kindly donated by Dr. Alexander Sorkin (University of Pittsburgh). Cells were grown at $37^{\circ} \mathrm{C}$ with 
275

276

277

278

279

280

281

282

283

284

285

286

287

288

289

290

291

292

293

294

$5 \% \mathrm{CO}_{2}$ in phenol-free Dulbecco's modified Eagle's medium (DMEM) (Thermo-Fisher, Gibco ${ }^{\mathrm{TM}}$, 31053028) containing $4.5 \mathrm{~g} / \mathrm{L}$ glucose and supplemented with $10 \%(\mathrm{v} / \mathrm{v})$ fetal bovine serum (Atlanta Biologicals, S10350), $50 \mathrm{mg} / \mathrm{mL}$ streptomycin - $50 \mathrm{U} / \mathrm{mL}$ penicillin (Thermo-Fisher, Gibco ${ }^{\mathrm{TM}}$, 15070063), 1\% v/v Glutamax (Thermo-Fisher, 35050061), and 1 mM sodium pyruvate (Thermo-Fisher, Gibco ${ }^{\mathrm{TM}}$, 11360070). Cell lines were used from low-passage frozen stocks and monitored for mycoplasma contamination. For experiments, cells were grown on $25 \mathrm{~mm}$ diameter rat tail collagen I-coated coverslips (Neuvitro Corporation, GG-25-1.5-collagen). For transfections, cells were incubated for $4 \mathrm{~h}$ with $500 \mathrm{ng}$ of the indicated plasmid(s) and $5 \mu \mathrm{L}$ of Lipofectamine 3000 (Thermo-Fisher, L3000015) in OptiMEM (Thermo-Fisher, Gibco ${ }^{\mathrm{TM}}$, 31985062). Experiments were performed $18 \mathrm{~h}$ after transfection.

\section{Plasmids}

EGFR-GFP \#32751, Src-GFP \#110496, Src-mCherry \#55002, $\alpha$ V-integrin-mEmerald \#53985, $\beta 1$-integrinGFP \#69804 were purchased from Addgene. $\beta 5$-integrin-GFP was kindly donated by Dr. Staffan Strömblad (Karolinska Institutet). EGFR-mScarlet, mScarlet-CLCa, $\beta 3$-integrin-GFP, $\beta 6$-integrin-GFP, $\beta 5$ integrin-GFP lacking 743-799 amino acids $(\Delta C)$, $\beta 5$-integrin-GFP containing point mutations Tyr766, 774, 794Phe (3Y-F), Tyr766, 774, 794Glu (3YE), and Ser759, 762Ala (2S-A), were built using either Q5 SiteDirected Mutagenesis Kit (New England Biolabs, E0554S) or In-Fusion HD Cloning Plus (Clonetech, 638911) following manufacturer's instructions. All plasmids were confirmed by sequencing (Psomagen).

\section{EGF pulse-chase stimulation and drug treatments}

Cells were incubated in starvation buffer (DMEM containing $4.5 \mathrm{~g} / \mathrm{L} \mathrm{D-glucose,} \mathrm{supplemented} \mathrm{with} 1 \%$ v/v Glutamax and $10 \mathrm{mM}$ HEPES) for $2 \mathrm{~h}$ before the pulse-chase assay. Then, cells were pulsed in starvation buffer supplemented with $0.1 \% \mathrm{w} / \mathrm{v}$ bovine serum albumin at $4{ }^{\circ} \mathrm{C}$ for $40 \mathrm{~min}$ with $50 \mathrm{ng} / \mathrm{mL}$ human recombinant EGF (Thermo-Fisher, Gibco ${ }^{\mathrm{TM}}$, PHG0311L) to allow ligand bind to the EGFR. In brief, 
cells were washed twice with PBS (Thermo-Fisher, Gibco ${ }^{\text {TM }}$, 10010023). Synchronized receptor activation

301 (Santa Cruz Biotechnology, 184475-35-2), $10 \mu \mathrm{M}$ PP2 (Thermo-Scientific, 172889-27-9), and $10 \mu \mathrm{M}$

302 cilengitide acid (CTA) (Sigma-Aldrich, SML1594), respectively.

\section{Cell unroofing and fixation}

After EGF pulse-chase stimulations, cells were rinsed briefly with stabilization buffer (30 mM HEPES, 70 $\mathrm{mM} \mathrm{KCl}, 5 \mathrm{mM} \mathrm{MgCl}$, $3 \mathrm{mM}$ EGTA, pH 7.4). Fixed cell membranes were obtained with application of unroofing buffer containing $2 \%$ paraformaldehyde in stabilization buffer using a $10 \mathrm{~mL}$ syringe with a unroofing. Afterwards, the coverslips were moved to fresh unroofing buffer containing $2 \%$ paraformaldehyde for $20 \mathrm{~min}$. They were rinsed $4 \times$ with PBS followed by electron or fluorescent microscopy preparation.

\section{Platinum replica electron microscopy (PREM)}

312 Coverslips were transferred from glutaraldehyde into $0.1 \% \mathrm{w} / \mathrm{v}$ tannic acid for $20 \mathrm{~min}$. Then,

313 coverslips were rinsed $4 \times$ with water, and placed in $0.1 \% \mathrm{w} / \mathrm{v}$ uranyl acetate for $20 \mathrm{~min}$. The coverslips were dehydrated, critical point dried, and coated with platinum and carbon as previously described ${ }^{40}$. The replicas were separated from glass coverslips using hydrofluoric acid and mounted on glow-discharged Formvar/carbon-coated 75-mesh copper TEM grids (Ted Pella 01802-F).

317 Transmission Electron Microscopy imaging was performed as previously described ${ }^{67}$ at $15,000 \times$ 
montage was manually segmented in image ${ }^{68}$ by outlining the edge of the membrane, flat clathrin structures (no visible curvature), domed clath rin structures (curved but can still see the edge of the lattice), and sphere clathrin structures (curved beyond a hemisphere such that the edge of the lattice

323 is no longer visible) as previously described ${ }^{41}$. The percentage of occupied membrane area was

324 defined as the sum of areas from clathrin of the specified subtype divided by the total area of visible 325 membrane.

327 Unroofed cells were incubated in PBS containing $3 \% \mathrm{w} / \mathrm{v}$ bovine serum albumin (Fisher Bioreagents, BP9703) and 0.1\% v/v triton X-100 (Sigma-Aldrich, T9284) for $1 \mathrm{~h}$ at room temperature. The cells were then immunolabelled with the indicated primary antibodies for $1 \mathrm{~h}$ at room temperature:

337 immediately or refrigerated overnight.

Total Internal Reflection Microscopy (TIRFM)

340 NA objective (Olympus). Combined green $(488 \mathrm{~nm})$ and red (561 nm) lasers (Melles Griot) were

341 controlled with an acousto-optic tunable filter (Andor) and passed through a LF405/488/561/635

342 dichroic mirror. Emitted light was filtered using a 565 DCXR dichroic mirror on the image splitter 
343 (Photometrics), passed through 525Q/50 and 605Q/55 filters and projected onto the chip of an

344 electron-multiplying charge-coupled device (EMCCD) camera. Images were acquired using the Andor IQ2

345 software. Cells were excited with alternate green and red excitation light, and images in each channel

346 were acquired at 500-ms exposure at $5 \mathrm{~Hz}$. Automated correlation analysis was performed on aligned

347 images as described previously ${ }^{48}$ and the fluorescence intensity signal at the plasma membrane was

348 assessed using ImageJ software by measuring the integrated density (mean gray value) of the

349 background subtracted from that of the cell and normalizing this value to the total cell area.

\section{$350 \quad$ In silico analysis}

351 Integrin sequences were obtained from the UniProt Knowledgebase. $\beta 5$-integrin orthologs: $H$.

352 sapiens (ID P18084); M. musculus (ID 070309); B. taurus (ID P80747); P. cynocephalus (ID Q07441); X.

353 laevis (ID Q6DF97); D. rerio (ID F1Q7R1). Integrin orthologs: $\beta 1$-integrin (ID P05556); $\beta 2$-integrin (ID

354 P05107); $\beta 3$-integrin (ID P05106); $\beta 6$-integrin (ID P18564); $\beta 7$-integrin (ID P26010). The sequence

355 alignments were performed using the blast-protein suite (protein-protein BLAST,

356 (http://www.uniprot.org/blast/). The prediction of phosphorylation sites was obtained using

357 NetPhos 3.0 (http://www.cbs.dtu.dk/services/NetPhos) and the Group-based Prediction System, GPS

3582.0 (http://gps.biocuckoo.org/) on-line services, employing cut-off values of 0.75 and 4, respectively.

359 Prediction of the probable protein kinases involved was obtained using GPS 2.0.

\section{In vitro kinase assay}

361 Identification of the $\beta 5$-integrin carboxyl domain as Src substrate was determined using the ADP-Glo

362 Kinase Assay (Promega, V6930) following protocols recommended by the manufacturer. All reactions

363 were performed in kinase buffer (40 mM Tris, $\mathrm{pH} 7.5,20 \mathrm{mM} \mathrm{MgCl}_{2}, 2 \mathrm{mM} \mathrm{MsSO}_{4}, 100 \mathrm{mM} \mathrm{Na}_{3} \mathrm{VO}_{4}$,

$36410 \mathrm{mM}$ DTT) supplemented with $50 \mathrm{mM}$ ATP, $1 \mathrm{mM}$ of the indicated peptide, and $50 \mathrm{ng}$ of purified

365 active Src (Millipore-Sigma, 14-326) or PAK (Millipore-Sigma, 14-584). $\beta$ 5-integrin peptide 
corresponding to amino acids 743-799 and Y766, 774, 794F were chemically synthetized (Biobasic). As a

367 positive control we used a bona fide Src substrate peptide corresponding to amino acids 6-20 of

$368 \mathrm{p} 34^{\text {cdc2 }}$ (Millipore-Sigma, 12-140). The reactions were carried out at room temperature in a total

369 volume of $25 \mu \mathrm{L}$ for 40 min in white 96-well, F-bottom, non-binding microplates (Greiner Bio-one,

370 655904). Signal was recorded using a luminometer (Biotek) with an integration time of $0.5 \mathrm{s.}$

\section{Statistics}

372 Data were tested for normality and equal variances with Shapiro-Wilk. The statistical tests were chosen

373 as follows: unpaired normally distributed data were tested with a two-tailed $t$-test (in the case of similar

374 variances) or with a two-tailed $t$-test with Welch's correction (in the case of different variances). All tests

375 were performed with Origin 2015.

\section{Data availability}

377 All data supporting this work are available upon request to the corresponding author.

\section{Author contributions}

379 MAAM, KAS and JWT designed experiments. KAS developed software for data analysis. MAAM

380 performed experiments and analyzed data. MPS performed molecular cloning and helped with in vitro

381 phosphorylation assays. MAAM wrote and JWT edited the manuscript and all authors commented on

382 the work. JWT supervised the project.

\section{Acknowledgements}

384 We would like to thank the NHLBI Electron Microscopy core for support with EM imaging and

385 instrumentation, Xufeng Wu and the NHLBI light Microscopy core for support with fluorescence imaging 386 and instrumentation, Ethan Tyler of NIH Medical Arts Department for the creation of Figure 6, Agila

387 Somasundaram, and members of the Taraska laboratory for discussion and comments on the 
manuscript. JWT is supported by the NHLBI Intramural Research Program, National Institutes of Health,

Bethesda, Maryland.

\section{Declaration of Interests}

The authors declare no competing interest.

\section{FIGURE LEGENDS}

Figure 1. EGF modifies the ultrastructure of clathrin at the plasma membrane. a, Montaged PREM

395 image of an unroofed control HSC3-EGFR-GFP cell and the mask created after segmentation of the full membrane outlined (yellow). Flat, dome, and sphere clathrin-coated structures (CCCs) are shown in green, blue, and magenta, respectively. b, High-magnification of the cropped PREM in (a); the different segmented CCSs are color-coded as in (a), with native grayscale in magnified insets. c, Montaged PREM image of an unroofed HSC3-EGFR-GFP cell treated with $50 \mathrm{ng} / \mathrm{mL}$ EGF for 15 min and the mask created

magnification insets are shown at the same scale and are outlined with dashed squares in each image. e,

median. 0 min: $N_{\text {flat }}=141, N_{\text {dome }}=46, N_{\text {sphere }}=68, N_{\text {cells }}=4 ; 2$ min: $N_{\text {flat }}=164, N_{\text {dome }}=32, N_{\text {sphere }}=30, N_{\text {cells }}=3 ; 5$

$\min : N_{\text {flat }}=184, N_{\text {dome }}=26, N_{\text {sphere }}=36, N_{\text {cells }}=4 ; 15$ min: $N_{\text {flat }}=559, N_{\text {dome }}=67, N_{\text {sphere }}=207, N_{\text {cells }}=4 ; 30$ min: 
$N_{\text {flat }}=395, N_{\text {dome }}=149, N_{\text {sphere }}=113, N_{\text {cells }}=3 ; 60$ min: $N_{\text {flat }}=81, N_{\text {dome }}=15, N_{\text {sphere }}=57, N_{\text {cells }}=5$. Scale bars in (a)

and (c) are $5000 \mathrm{~nm}$. Scale bars in (b, d, e) are $1 \mu \mathrm{m}$; insets are $200 \mathrm{~nm}$.

Figure 2. Flat clathrin lattice formation requires EGFR, Src and $\beta 5$-integrin. a, Representative PREMs of control HSC3-EGFR-GFP cells (Ctrl), (b) treated either with $50 \mathrm{ng} / \mathrm{mL}$ EGF alone (EGF) for $15 \mathrm{~min}$ in presence of (c) $10 \mu \mathrm{M}$ gefitinib (Gefi+EGF), (d) $10 \mu \mathrm{M}$ PP2 (PP2+EGF) and (e) $10 \mu \mathrm{M}$ cilengitide acid

416 (CTA+EGF). The magnification insets are shown at the same scale and are outlined with dashed squares

417 in each image. Flat, dome and sphere clathrin-coated structures (CCSs) are shown in green, blue and

Figure 3. Differential location of EGFR, Src and $\beta 5$-integrin in clathrin coated structures. a, 
mean (square) and minimum and maximum data point whiskers with a coefficient value of 1.5.

435 Significance was tested by a two-tailed unpaired t-test. EGFR, ${ }^{*} P=5.9 \times 10^{-7} ; \operatorname{Src},{ }^{*} P=1.7 \times 10^{-11} ; \beta 5$ integrin, ${ }^{\text {ns }} P=0.358 . N_{\text {EGFR-Ctrl }}=23$ cells -3728 spots, $N_{\text {EGFR-EGF }}=22$ cells -2173 spots, $N_{\text {src-Ctrl }}=28$ cells 1394 spots, $\mathrm{N}_{\text {Src-EGF }}=27$ cells -1407 spots, $\mathrm{N}_{\beta 5-\mathrm{Ctrl}}=21$ cells -1037 spots; $\mathrm{N}_{\beta 5-\mathrm{EGF}}=29$ cells -1011 spots.

Figure 4. $\beta 5$-integrin phosphorylation controls spatial correlation with clathrin. a, Diagram of $\beta 5$ -

440 integrin and magnification of the cytoplasmic domain showing different mutants. Numbers indicate the residue positions, and letters identify the amino acid. Truncated line in the diagram, indicates deletion of sequence coding for amino acids 743-799, Wild type (WT), carboxyl truncated $(\Delta C)$, nonephosphorylatable (3Y-F), phosphomimetic (3Y-E), and PAK-targeted (2S-A). b, In vitro phosphorylation assay using purified Src or PAK4 and peptides corresponding to the $\beta 5$-integrin carboxyl domain (742799) WT and mutants in (a). Significance was tested by a two-tailed unpaired t-test, ${ }^{*} P=1.51 \times 10^{-4}$, ${ }^{* *} P=0.002,{ }^{* *} P=1.09 \times 10^{-5},{ }^{\text {ns }} \mathrm{P}=0.0205 . \mathrm{N}=4,6,5,6,6 . \mathrm{c}$, Representative TIRF images of HSC3 WT cells

451 value of 1.5. Significance was tested by a two-tailed unpaired t-test, ${ }^{\mathrm{ns}} P_{\beta 5-\mathrm{WT}}=0.0811, * * * P_{\beta 5-\Delta \mathrm{C}}=4.03 \times 10^{-7}$,

454 spots, $N_{\beta 5-3 Y-F-E G F}=17$ cells -1099 spots, $N_{\beta 5-3 Y-E-C r r l}=17$ cells -1245 spots, $N_{\beta 5-3 Y-E-E G F}=16$ cells -1122 spots, 
Figure 5. Flat clathrin lattices partition sustained signals at the plasma membrane. a, Representative mScarlet-CLCa and immunolabeled with anti-phospho EGFR (P-EGFR) coupled to Alexa 647, treated with

correlation analysis of $(\mathrm{a}) .{ }^{*} P=1.11 \times 10^{-19}, * * P=1.70 \times 10^{-5} . \mathrm{N}_{\mathrm{Ctrl}}=30$ cells, $\mathrm{N}_{\mathrm{EGF}}=25$ cells, $\mathrm{N}_{\mathrm{CTA}+\mathrm{EGF}}=23$ cells. c,

EGFR-GFP (T-EGFR). ${ }^{*} P=1.95 \times 10^{-4}, * * P=6.00 \times 10^{-4} . \mathrm{N}_{\text {Ctrl }}=29$ cells, $\mathrm{N}_{\mathrm{EGF}}=18$ cells, $\mathrm{N}_{\mathrm{CTA}+\mathrm{EGF}}=18$ cells. e,

$467 \mathrm{~N}_{\mathrm{Ctrl}}=27$ cells, $\mathrm{N}_{\mathrm{EGF}}=38$ cells, $\mathrm{N}_{\mathrm{CTA}+\mathrm{EGF}}=23$ cells. $\mathrm{g}$, Fluorescence intensity measurements of the signal

472 fluorescence arbitrary units.

Figure 6. Model of flat clathrin lattices biogenesis during growth factor response. The critical steps of

477 3) this in parallel allows the biding of the downstream scaffold Grb2 and locally activates Src; 4) which in

478 turn phosphorylates $\beta 5$-integrin cytoplasmic domain; 5 ) the maintenance of the EGFR/Src/ $\beta 5$-integrin

479 axis promotes flat clathrin lattice growth. A key implication of this model is that two different receptor systems are spatially organized at the nanoscale within flat clathrin lattices. 


\section{SUPPLEMENTARY FIGURE LEGENDS}

\section{Supplementary Figure 1. EGF increases the density of clathrin at the plasma membrane. a,}

485 Representative PREM images of the flat (green), dome (blue), and sphere (magenta) clathrin-coated structures (CCSs) segmented in Fig. 1. Scale bars are $100 \mathrm{~nm}$. b, Morphometric analysis of the images of control (Ctrl) HSC3-EGFR-GFP cells or treated with $50 \mathrm{ng} / \mathrm{mL}$ EGF for 2, 5, 15, 30 and 60 min and maximum data point whiskers with a coefficient value of 1.5. 0 min: $N_{\text {cells }}=4 ; 2$ min: $N_{\text {cells }}=3 ; 5$ min: signal from clathrin heavy chain. Control (Ctrl) unroofed HSC3-EGFR-GFP cells or treated with $50 \mathrm{ng} / \mathrm{mL}$ EGF were immunolabeled with anti-clathrin heavy chain coupled to Alexa 647. Ctrl: $\mathrm{N}_{\text {cells }}=5 ; \mathrm{EGF}: \mathrm{N}_{\text {cells }}=8$.

\section{Supplementary Figure 2. Original PREM images of cells from which the cropped images in Figure 1} were derived. PREM images of control (Ctrl) HSC3-EGFR-GFP cells, stimulated with $50 \mathrm{ng} / \mathrm{mL}$ EGF for 0,

Supplementary Figure 3. Morphometric analysis of PREM images of cells treated with different drugs. 
of the size of (d) dome and (e) sphere clathrin structures in cells treated as in (a-c). Dot plots show every structure segmented, the bar indicate the median. $\mathbf{f}-\mathbf{h}$, Morphometric analysis of the percentage of plasma membrane (PM) area occupation for (f) flat, (g) dome, and (h) sphere structures in control (Ctrl) cells or treated only with the drugs in (a-c). i-k, Morphometric analysis of the size of (i) flat, (j) dome and (k) sphere clathrin structures in cells treated as in (f-h). Ctrl: $N_{\text {flat }}=141, N_{\text {dome }}=46, N_{\text {sphere }}=68 ; N_{\text {cells }}=4$; EGF: $N_{\text {flat }}=559, N_{\text {dome }}=67, N_{\text {sphere }}=207, N_{\text {cells }}=4 ;$ Gefi: $N_{\text {flat }}=153, N_{\text {dome }}=65, N_{\text {sphere }}=72, N_{\text {cells }}=4 ;$ Gefi+EGF: $N_{\text {flat }}=160$, $N_{\text {dome }}=69, N_{\text {sphere }}=103, N_{\text {cells }}=4 ; P P 2: N_{\text {flat }}=109, N_{\text {dome }}=36, N_{\text {sphere }}=53, N_{\text {cells }}=3 ; P P 2+E G F: N_{\text {flat }}=267, N_{\text {dome }}=88$, $N_{\text {sphere }}=61, N_{\text {cells }}=4 ; C T A: N_{\text {flat }}=171, N_{\text {dome }}=137, N_{\text {sphere }}=229, N_{\text {cells }}=4 ; C T A+E G F: N_{\text {flat }}=244, N_{\text {dome }}=68$, $\mathrm{N}_{\text {sphere }}=167, \mathrm{~N}_{\text {cells }}=4$. i, Representative masks of segmented cells treated as in (f-h). I, Representative masks of segmented cells treated as in $(\mathbf{a}, \mathbf{f})$. Scale bar is Ctrl and EGF data are from Figure 1 and shown for reference.

\section{Supplementary Figure 4. Original PREM images of cells treated with different drugs. Original PREM} images of cells from which the cropped images in Figure 2 and masks in Supplementary Figure 2 were derived. Shown are control (Ctrl) HSC3-EGFR-GFP cells or treated with $50 \mathrm{ng} / \mathrm{mL}$ EGF for 15 min in the absence (EGF) or presence $10 \mu \mathrm{M}$ gefitinib (Gefi+EGF), $10 \mu \mathrm{M}$ PP2 (PP2+EGF), $10 \mu \mathrm{M}$ cilengitide acid (CTA+EGF) and the drugs alone (Gefi, PP2, CTA). Scale bars are $200 \mathrm{~nm}$.

\section{Supplementary Figure 5. EGFR-GFP correlates with clathrin after EGF stimulation. a, Representative} TIRF images of HSC3 WT cells co-transfected with mScarlet-CLCa and EGFR-GFP before (Ctrl) or after 50 $\mathrm{ng} / \mathrm{mL}$ EGF stimulation for $15 \mathrm{~min}$. b, Automated correlation analysis of (a). Significance was tested by a two-tailed unpaired t-test, ${ }^{*} P_{\text {EGFR }}=4 \cdot 2 \times 10^{-7} . N_{\text {EGFR-Ctrl }}=22$ cells -1148 spots, $N_{\text {EGFR-EGF }}=24$ cells -1305 spots. Dot box plots show median extended from 25 th to 75 th percentiles, mean (square) and minimum 
and maximum data point whiskers with a coefficient value of 1.5 . Scale bar is $10 \mu \mathrm{m}$; insets are $7.3 \times 7.3$

$\mu \mathrm{m}$.

Supplementary Figure 6. Differential location of EGFR and Src in $\beta 5$-integrin enriched structures. a, correlation analysis of (a). Significance was tested by a two-tailed unpaired t-test ${ }^{*} P_{E G F R}=8.4 \times 10^{-4},{ }^{*} P_{S r C}=$

$1.2 \times 10^{-6} . N_{\text {EGFR-Crrl }}=17$ cells -1516 spots, $N_{\text {EGFR-EGF }}=16$ cells -1416 spots, $N_{\text {Src-Ctrl }}=24$ cells -1936 spots, $\mu \mathrm{m}$; insets are $7.3 \times 7.3 \mu \mathrm{m}$.

Supplementary Figure 7. Clathrin coated structures are mainly enriched with $\beta 5$-integrin. Automated correlation analysis of HSC3 WT cells co-transfected with mScarlet-CLCa and the indicated integrin tagged with GFP before (Ctrl) or after $50 \mathrm{ng} / \mathrm{mL}$ EGF stimulation for $15 \mathrm{~min}$. Cell were imaged using TIRFM. Dot box plots show median extended from 25 th to 75 th percentiles, mean (square) and minimum and maximum data point whiskers with a coefficient value of 1.5. Dots represent the mean correlation value of independent experiments.

Supplementary Figure 8. In silico analysis of $\beta 5$-integrin. a, Sequence alignment of cytoplasmic domain of different $\beta 5$-integrin orthologues. Tyrosine residues are marked in green. Symbols: i) ${ }^{*}$, single fully conserved residue; ii) : , conservative; iii) . , noneconservative. b, Sequence alignment of cytoplasmic domain of different $\beta$-integrin subfamily members. Symbols as in (a). c, Bioinformatic prediction of the possible protein kinases involved in the posttranslational modification of the $\beta 5$-integrin cytoplasmic 
domain. The phosphopeptides identified by Netphos 3 and GPS 5 are indicated with the putative

modified residues in magenta; the residue position is indicated, as well as the protein kinases most likely

the indicated bioinformatic tool.

\section{REFERENCES}

1. Lemmon, M.A. \& Schlessinger, J. Cell signaling by receptor tyrosine kinases. Cell 141, 1117-1134 (2010).

2. Chong, C.R. \& Janne, P.A. The quest to overcome resistance to EGFR-targeted therapies in cancer. Nat Med 19, 1389-1400 (2013).

3. Sigismund, S., Avanzato, D. \& Lanzetti, L. Emerging functions of the EGFR in cancer. Mol Oncol 12, 3-20 (2018).

4. Ogiso, H. et al. Crystal structure of the complex of human epidermal growth factor and receptor extracellular domains. Cell 110, 775-787 (2002).

5. Salazar-Cavazos, E. et al. Multisite EGFR phosphorylation is regulated by adaptor protein abundances and dimer lifetimes. Mol Biol Cell 31, 695-708 (2020).

6. Schlessinger, J. Ligand-induced, receptor-mediated dimerization and activation of EGF receptor.

Cell 110, 669-672 (2002).

7. Kim, L.C., Song, L. \& Haura, E.B. Src kinases as therapeutic targets for cancer. Nat Rev Clin Oncol 6, 587-595 (2009).

8. Parsons, J.T. \& Parsons, S.J. Src family protein tyrosine kinases: cooperating with growth factor and adhesion signaling pathways. Curr Opin Cell Biol 9, 187-192 (1997).

9. Sorkin, A., McClure, M., Huang, F. \& Carter, R. Interaction of EGF receptor and grb2 in living cells visualized by fluorescence resonance energy transfer (FRET) microscopy. Curr Biol 10, 1395-1398 (2000).

10. Chen, Z. et al. EGFR family and Src family kinase interactions: mechanics matters? Curr Opin Cell Biol 51, 97-102 (2018).

11. Ivaska, J. \& Heino, J. Cooperation between integrins and growth factor receptors in signaling and endocytosis. Annu Rev Cell Dev Biol 27, 291-320 (2011).

12. Bachmann, M., Kukkurainen, S., Hytonen, V.P. \& Wehrle-Haller, B. Cell Adhesion by Integrins. Physiol Rev 99, 1655-1699 (2019).

13. Kechagia, J.Z., Ivaska, J. \& Roca-Cusachs, P. Integrins as biomechanical sensors of the microenvironment. Nat Rev Mol Cell Biol 20, 457-473 (2019).

14. Hamidi, H. \& Ivaska, J. Every step of the way: integrins in cancer progression and metastasis. Nat Rev Cancer 18, 533-548 (2018). 
602

603

604

605

606

607

608

609

610

611

612

613

614

615

616

617

618

619

620

621

622

623

624

625

626

627

628

629

630

631

632

633

634

635

636

15. Luo, B.H., Carman, C.V. \& Springer, T.A. Structural basis of integrin regulation and signaling. Annu Rev Immunol 25, 619-647 (2007).

16. Calderwood, D.A. et al. Integrin beta cytoplasmic domain interactions with phosphotyrosinebinding domains: a structural prototype for diversity in integrin signaling. Proc Natl Acad Sci U S A 100, 2272-2277 (2003).

17. Uhlik, M.T. et al. Structural and evolutionary division of phosphotyrosine binding (PTB) domains. J Mol Biol 345, 1-20 (2005).

18. Legate, K.R. \& Fassler, R. Mechanisms that regulate adaptor binding to beta-integrin cytoplasmic tails. J Cell Sci 122, 187-198 (2009).

19. Zuidema, A. et al. Mechanisms of integrin alphaVbeta5 clustering in flat clathrin lattices. J Cell Sci 131 (2018).

20. Schmid, S.L. Reciprocal regulation of signaling and endocytosis: Implications for the evolving cancer cell. J Cell Biol 216, 2623-2632 (2017).

21. Sorkin, A. \& von Zastrow, M. Endocytosis and signalling: intertwining molecular networks. Nat Rev Mol Cell Biol 10, 609-622 (2009).

22. Kaksonen, M. \& Roux, A. Mechanisms of clathrin-mediated endocytosis. Nat Rev Mol Cell Biol 19, 313-326 (2018).

23. Sochacki, K.A. \& Taraska, J.W. From Flat to Curved Clathrin: Controlling a Plastic Ratchet. Trends Cell Biol 29, 241-256 (2019).

24. Miller, S.E. et al. CALM regulates clathrin-coated vesicle size and maturation by directly sensing and driving membrane curvature. Dev Cell 33, 163-175 (2015).

25. Heuser, J. Three-dimensional visualization of coated vesicle formation in fibroblasts. J Cell Biol 84, 560-583 (1980).

26. Maupin, P. \& Pollard, T.D. Improved preservation and staining of HeLa cell actin filaments, clathrin-coated membranes, and other cytoplasmic structures by tannic acid-glutaraldehydesaponin fixation. J Cell Biol 96, 51-62 (1983).

27. Grove, J. et al. Flat clathrin lattices: stable features of the plasma membrane. Mol Biol Cell 25, 3581-3594 (2014).

28. Saffarian, S., Cocucci, E. \& Kirchhausen, T. Distinct dynamics of endocytic clathrin-coated pits and coated plaques. PLoS Biol 7, e1000191 (2009).

29. Franck, A. et al. Clathrin plaques and associated actin anchor intermediate filaments in skeletal muscle. Mol Biol Cell 30, 579-590 (2019).

30. Vassilopoulos, S. et al. Actin scaffolding by clathrin heavy chain is required for skeletal muscle sarcomere organization. J Cell Biol 205, 377-393 (2014).

31. Akisaka, T., Yoshida, H., Suzuki, R., Shimizu, K. \& Takama, K. Clathrin sheets on the protoplasmic surface of ventral membranes of osteoclasts in culture. J Electron Microsc (Tokyo) 52, 535-543 (2003).

32. Akisaka, T., Yoshida, H., Suzuki, R. \& Takama, K. Adhesion structures and their cytoskeletonmembrane interactions at podosomes of osteoclasts in culture. Cell Tissue Res 331, 625-641 (2008).

33. Leyton-Puig, D. et al. Flat clathrin lattices are dynamic actin-controlled hubs for clathrinmediated endocytosis and signalling of specific receptors. Nat Commun 8, 16068 (2017).

34. Baschieri, F. et al. Frustrated endocytosis controls contractility-independent mechanotransduction at clathrin-coated structures. Nat Commun 9, 3825 (2018).

35. De Deyne, P.G. et al. The vitronectin receptor associates with clathrin-coated membrane domains via the cytoplasmic domain of its beta5 subunit. J Cell Sci 111 (Pt 18), 2729-2740 (1998). 
662

663

664

665

666

667

668

669

670

671

672

673

674

675

676

677

678

679

680

681

682

683

36. Lock, J.G. et al. Reticular adhesions are a distinct class of cell-matrix adhesions that mediate attachment during mitosis. Nat Cell Biol 20, 1290-1302 (2018).

37. Kudo, Y. et al. Establishment of an oral squamous cell carcinoma cell line with high invasive and p27 degradation activities from a lymph node metastasis. Oral Oncol 39, 515-520 (2003).

38. Momose, F. et al. Variant sublines with different metastatic potentials selected in nude mice from human oral squamous cell carcinomas. J Oral Pathol Med 18, 391-395 (1989).

39. Pinilla-Macua, I., Grassart, A., Duvvuri, U., Watkins, S.C. \& Sorkin, A. EGF receptor signaling, phosphorylation, ubiquitylation and endocytosis in tumors in vivo. Elife 6 (2017).

40. Sochacki, K.A. \& Taraska, J.W. Correlative Fluorescence Super-Resolution Localization Microscopy and Platinum Replica EM on Unroofed Cells. Methods Mol Biol 1663, 219-230 (2017).

41. Sochacki, K.A., Dickey, A.M., Strub, M.P. \& Taraska, J.W. Endocytic proteins are partitioned at the edge of the clathrin lattice in mammalian cells. Nat Cell Biol 19, 352-361 (2017).

42. Sanford, M. \& Scott, L.J. Gefitinib: a review of its use in the treatment of locally advanced/metastatic non-small cell lung cancer. Drugs 69, 2303-2328 (2009).

43. Amanchy, R. et al. Identification of c-Src tyrosine kinase substrates in platelet-derived growth factor receptor signaling. Mol Oncol 3, 439-450 (2009).

44. Wilde, A. et al. EGF receptor signaling stimulates SRC kinase phosphorylation of clathrin, influencing clathrin redistribution and EGF uptake. Cell 96, 677-687 (1999).

45. Zimmerman, B., Simaan, M., Lee, M.H., Luttrell, L.M. \& Laporte, S.A. c-Src-mediated phosphorylation of AP-2 reveals a general mechanism for receptors internalizing through the clathrin pathway. Cell Signal 21, 103-110 (2009).

46. Hanke, J.H. et al. Discovery of a novel, potent, and Src family-selective tyrosine kinase inhibitor. Study of Lck- and FynT-dependent T cell activation. J Biol Chem 271, 695-701 (1996).

47. Mould, A.P., Craig, S.E., Byron, S.K., Humphries, M.J. \& Jowitt, T.A. Disruption of integrinfibronectin complexes by allosteric but not ligand-mimetic inhibitors. Biochem J 464, 301-313 (2014).

48. Larson, B.T., Sochacki, K.A., Kindem, J.M. \& Taraska, J.W. Systematic spatial mapping of proteins at exocytic and endocytic structures. Mol Biol Cell 25, 2084-2093 (2014).

49. Tice, D.A., Biscardi, J.S., Nickles, A.L. \& Parsons, S.J. Mechanism of biological synergy between cellular Src and epidermal growth factor receptor. Proc Natl Acad Sci U S A 96, 1415-1420 (1999).

50. Cheng, H.C., Nishio, H., Hatase, O., Ralph, S. \& Wang, J.H. A synthetic peptide derived from p34cdc2 is a specific and efficient substrate of src-family tyrosine kinases. J Biol Chem 267, 92489256 (1992).

51. Li, Z. et al. p21-activated kinase 4 phosphorylation of integrin beta5 Ser-759 and Ser-762 regulates cell migration. J Biol Chem 285, 23699-23710 (2010).

52. Scott, J.D. \& Pawson, T. Cell signaling in space and time: where proteins come together and when they're apart. Science 326, 1220-1224 (2009).

53. Fortian, A. \& Sorkin, A. Live-cell fluorescence imaging reveals high stoichiometry of Grb2 binding to the EGF receptor sustained during endocytosis. J Cell Sci 127, 432-444 (2014).

54. Kassenbrock, C.K., Hunter, S., Garl, P., Johnson, G.L. \& Anderson, S.M. Inhibition of Src family kinases blocks epidermal growth factor (EGF)-induced activation of Akt, phosphorylation of cCbl, and ubiquitination of the EGF receptor. J Biol Chem 277, 24967-24975 (2002).

55. Buwa, N., Mazumdar, D. \& Balasubramanian, N. Caveolin1 Tyrosine-14 Phosphorylation: Role in Cellular Responsiveness to Mechanical Cues. J Membr Biol (2020).

56. Reynolds, A.B. et al. SRChing for the substrates of Src. Oncogene 33, 4537-4547 (2014). 
57. Nolte, M.A., Nolte-'t Hoen, E.N.M. \& Margadant, C. Integrins Control Vesicular Trafficking; New Tricks for Old Dogs. Trends Biochem Sci (2020).

58. Baschieri, F., Porshneva, K. \& Montagnac, G. Frustrated clathrin-mediated endocytosis - causes and possible functions. J Cell Sci 133 (2020).

59. Chung, I. et al. Spatial control of EGF receptor activation by reversible dimerization on living cells. Nature 464, 783-787 (2010).

690

60. da Rocha-Azevedo, B. et al. Heterogeneity in VEGF Receptor-2 Mobility and Organization on the Endothelial Cell Surface Leads to Diverse Models of Activation by VEGF. Cell Rep 32, 108187 (2020).

61. Ibach, J. et al. Single Particle Tracking Reveals that EGFR Signaling Activity Is Amplified in Clathrin-Coated Pits. PLoS One 10, e0143162 (2015).

696

697

62. Low-Nam, S.T. et al. ErbB1 dimerization is promoted by domain co-confinement and stabilized

63. Kim, I. et al. Clathrin and AP2 are required for Ptdlns(4,5)P2-mediated formation of LRP6

signalosomes. J Cell Biol 200, 419-428 (2013).

64. Lampe, M., Pierre, F., Al-Sabah, S., Krasel, C. \& Merrifield, C.J. Dual single-scission event analysis of constitutive transferrin receptor (TfR) endocytosis and ligand-triggered beta2-adrenergic receptor (beta2AR) or Mu-opioid receptor (MOR) endocytosis. Mol Biol Cell 25, 3070-3080 (2014).

65. Roberts, A.D. et al. Structurally distinct endocytic pathways for B cell receptors in B lymphocytes. Mol Biol Cell, mbcE20080532 (2020).

66. Flores-Otero, J. et al. Ligand-specific endocytic dwell times control functional selectivity of the cannabinoid receptor 1. Nat Commun 5, 4589 (2014).

67. Mastronarde, D.N. Automated electron microscope tomography using robust prediction of specimen movements. J Struct Biol 152, 36-51 (2005).

68. Schindelin, J. et al. Fiji: an open-source platform for biological-image analysis. Nat Methods $\mathbf{9}$, 676-682 (2012). 
bioRxiv preprint doi: https://doi.org/10.1101/2020.11.09.373837; this version posted November 9, 2020. The copyright holder for this preprint (which was not certified by peer review) is the author/funder, who has granted bioRxiv a license to display the preprint in perpetuity. It is made available under aCC-BY-NC 4.0 International license.

Fig. 1

a

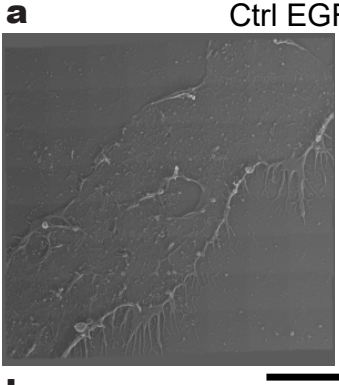

b

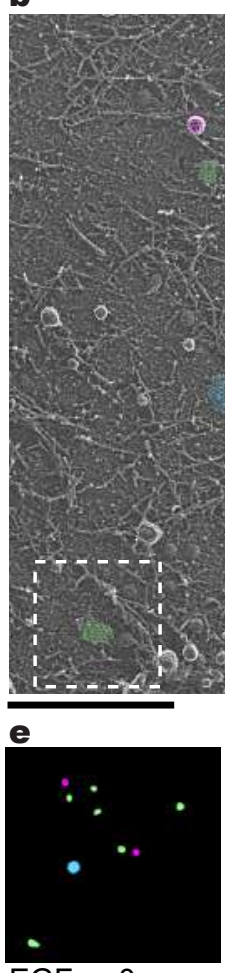

EGF 0

f

工

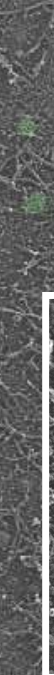

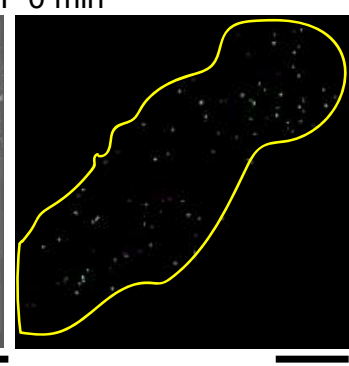
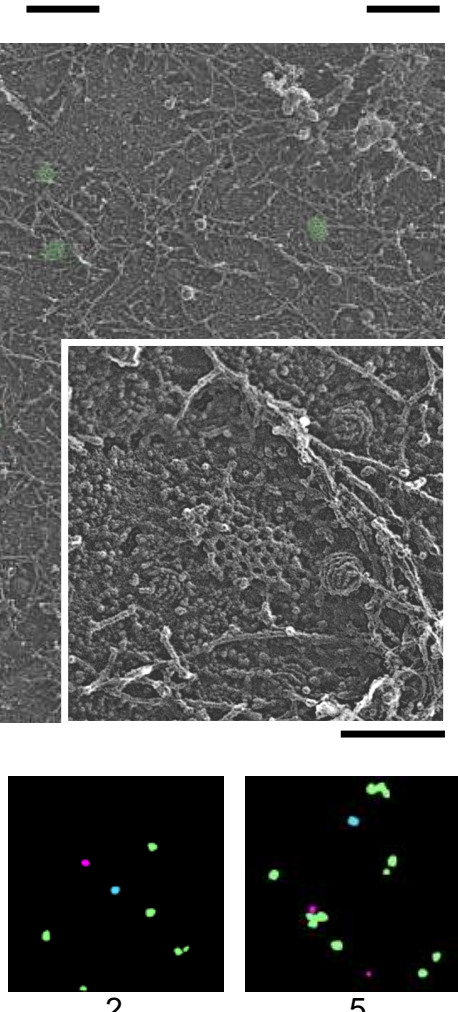

2

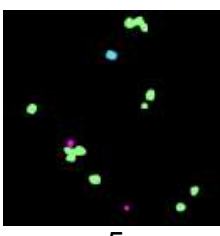

5
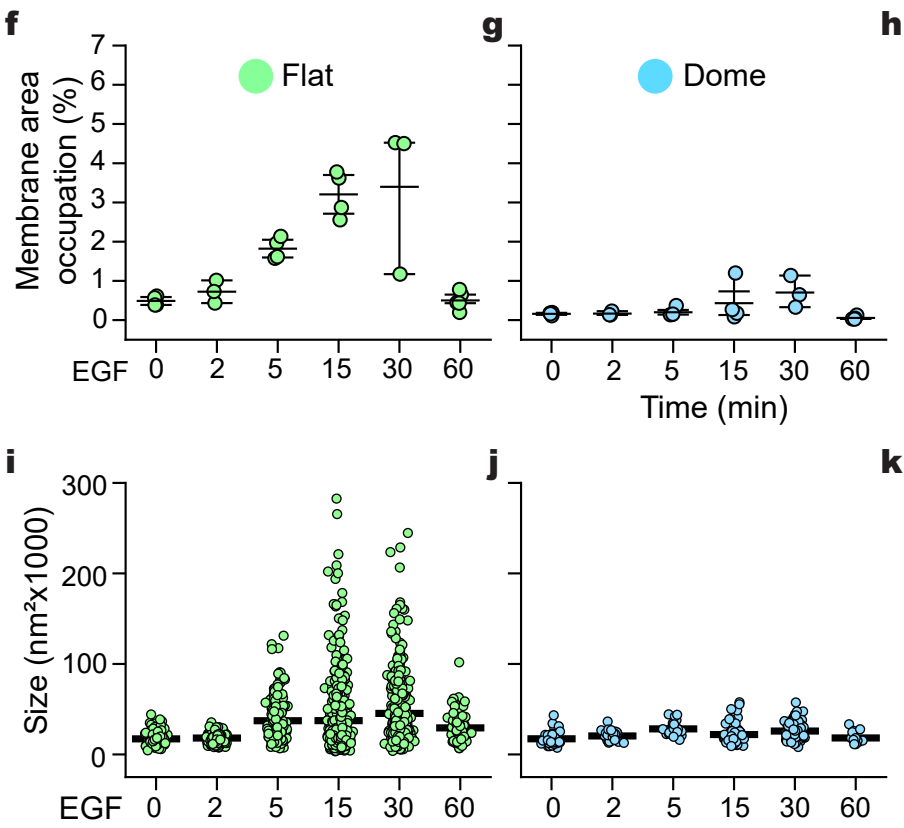

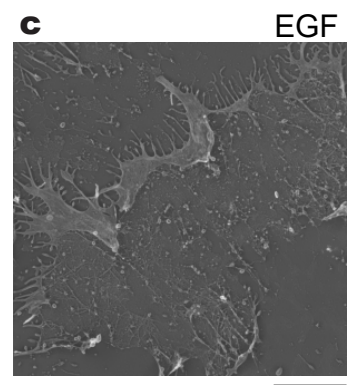

EGF $15 \mathrm{~min}$
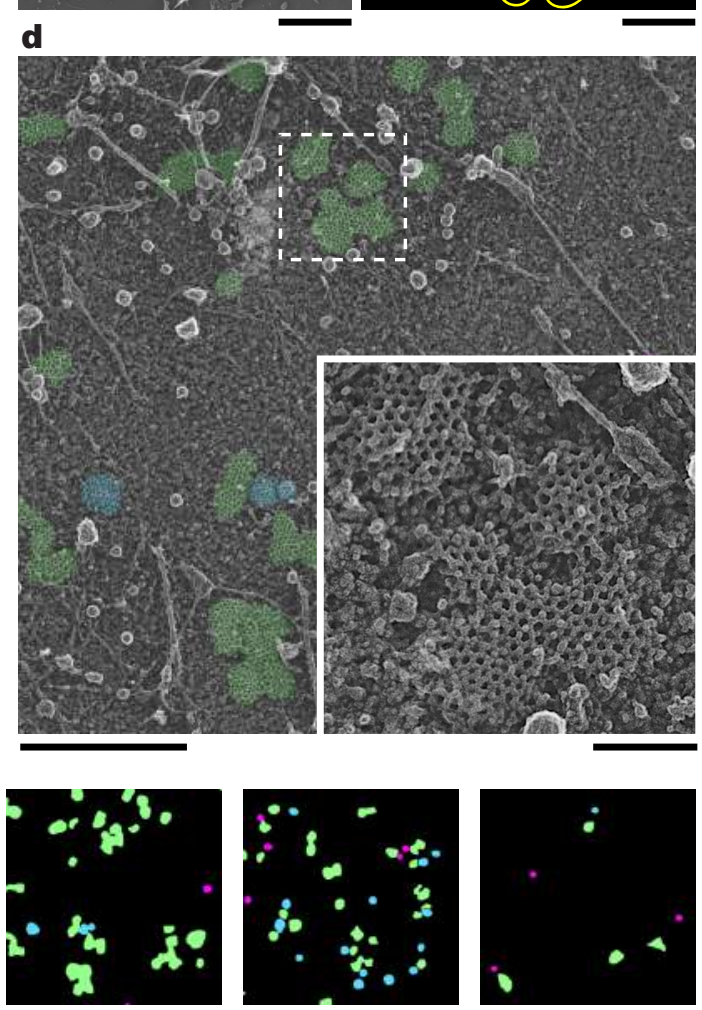

30

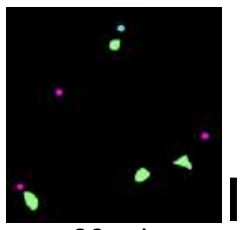

$60 \mathrm{~min}$

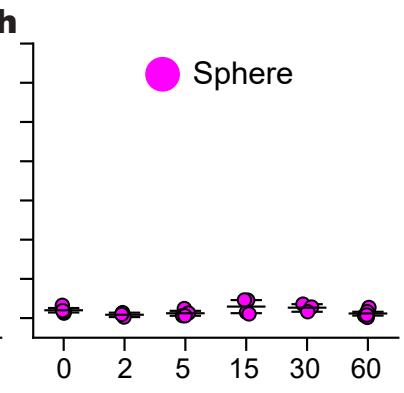

k

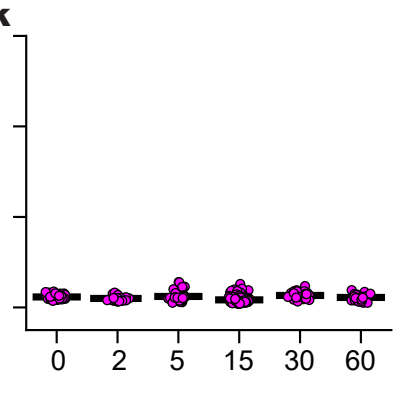


bioRxiv preprint doi: https://doi.org/10.1101/2020.11.09.373837; this version posted November 9, 2020. The copyright holder for this preprint

(which was not certified by peer review) is the author/funder, who has granted bioRxiv a license to display the preprint in perpetuity. It is made Fig. 2 available under aCC-BY-NC 4.0 International license.
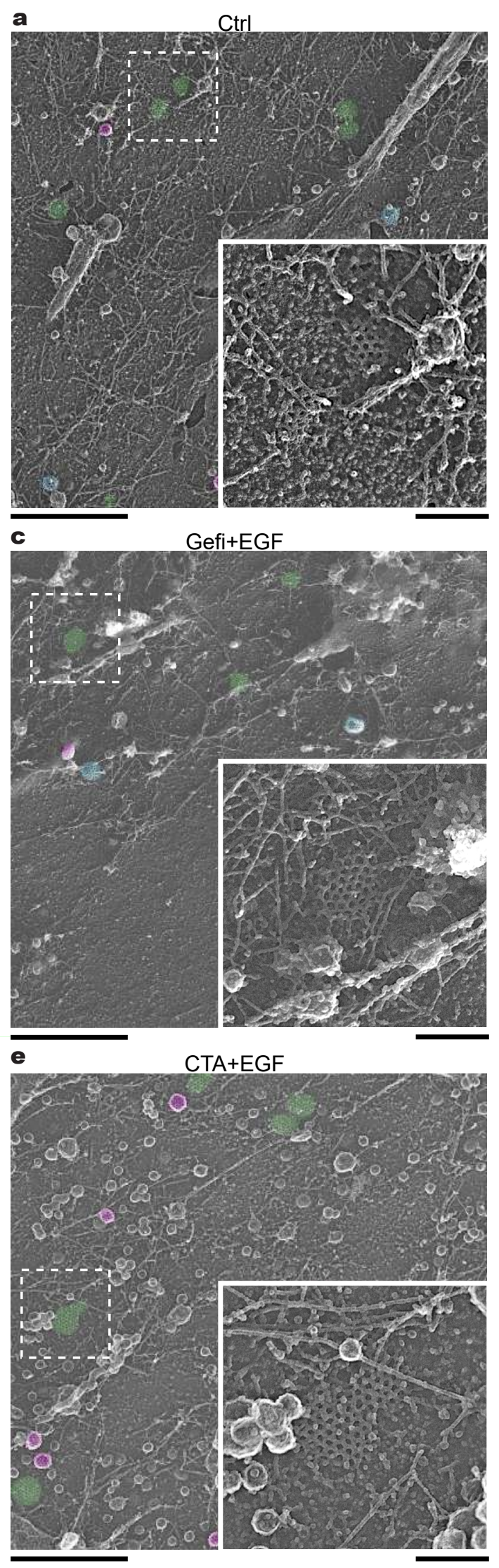

b
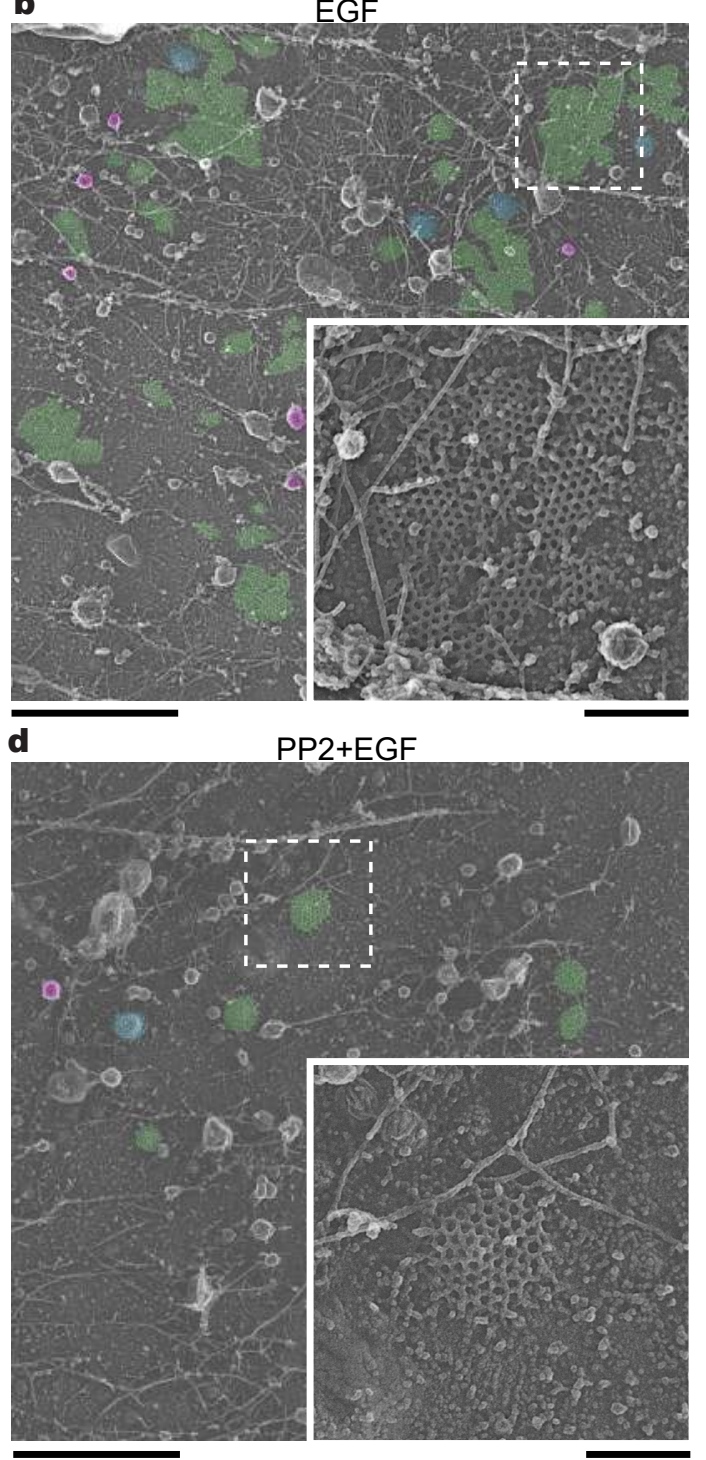

g

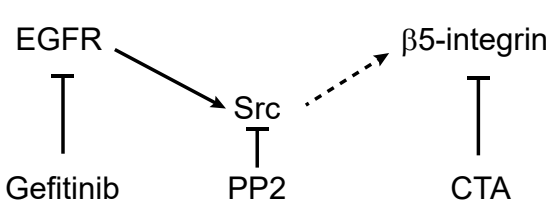

h
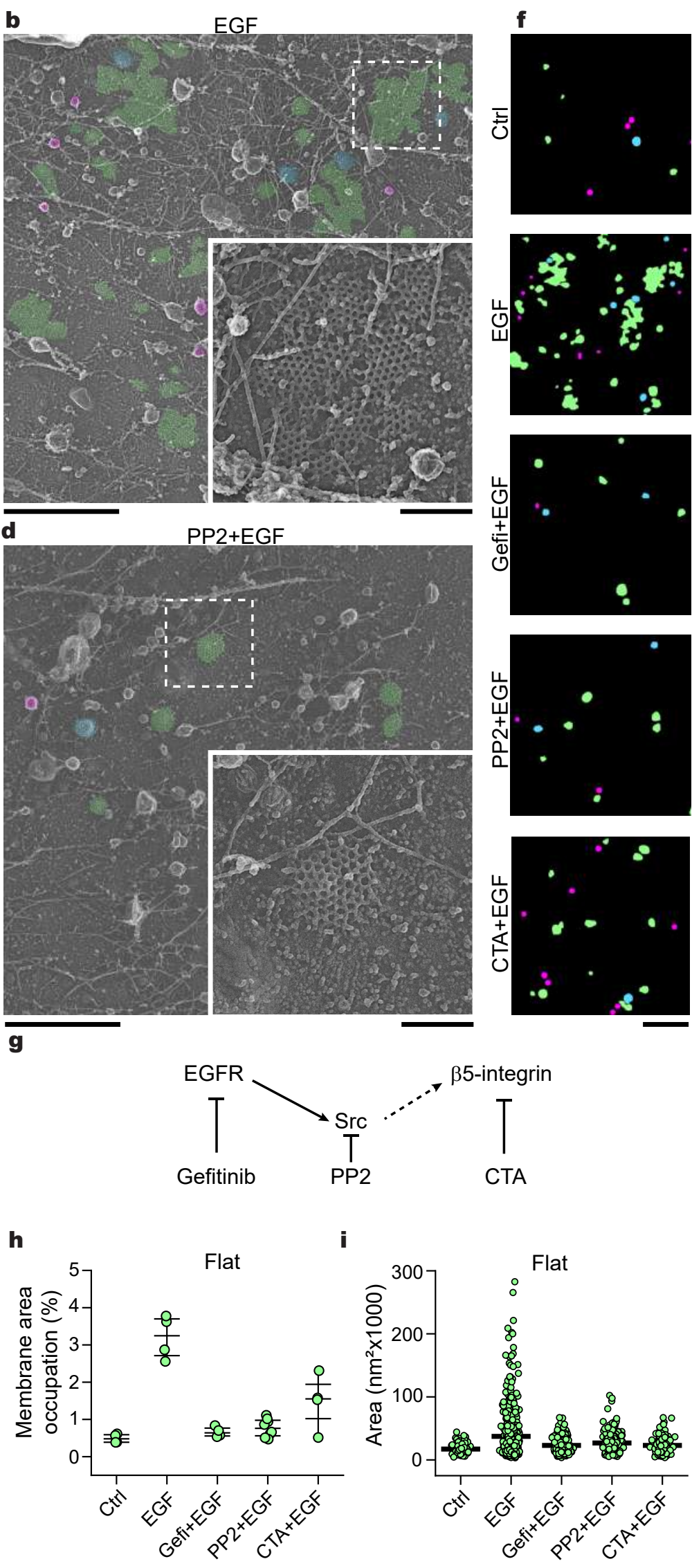

CTA 
bioRxiv preprint doi: https://doi.org/10.1101/2020.11.09.373837; this version posted November 9, 2020. The copyright holder for this preprint (which was not certified by peer review) is the author/funder, who has granted bioRxiv a license to display the preprint in perpetuity. It is made available under aCC-BY-NC 4.0 International license.

Fig. 3

a
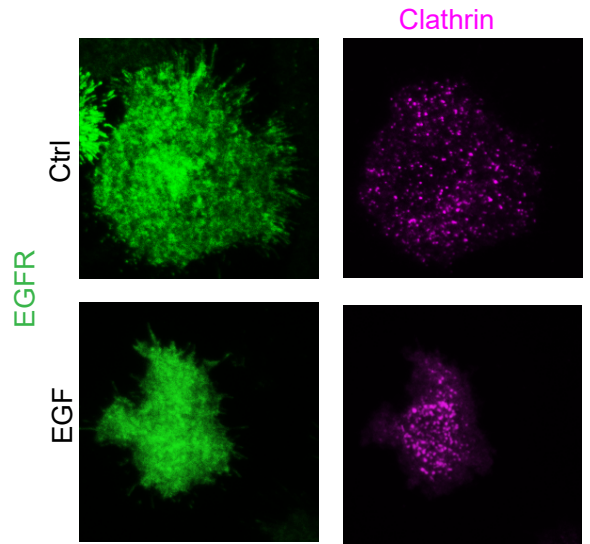

Overlay
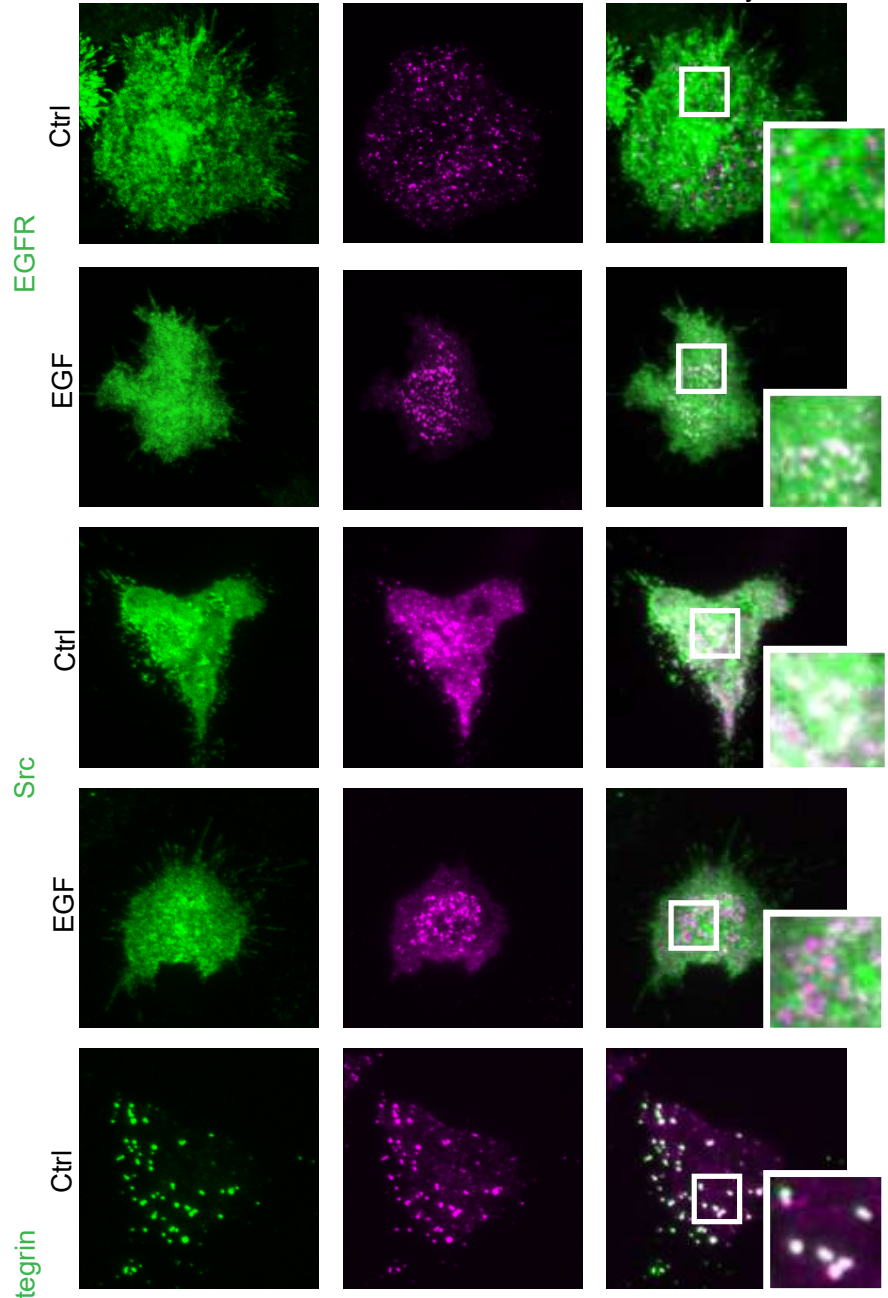

官
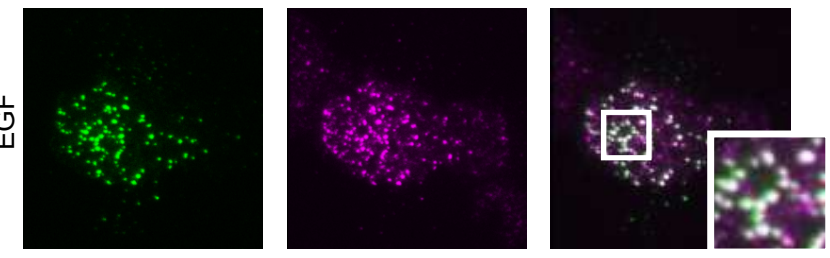

b

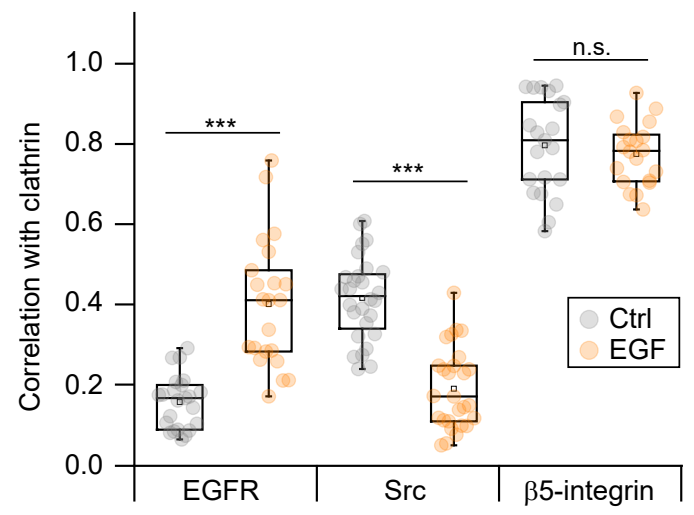


bioRxiv preprint doi: https://doi.org/10.1101/2020.11.09.373837; this version posted November 9, 2020. The copyright holder for this preprint (which was not certified by peer review) is the author/funder, who has granted bioRxiv a license to display the preprint in perpetuity. It is made available under aCC-BY-NC 4.0 International license.

Fig. 4

a

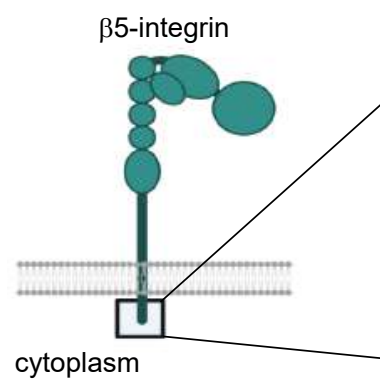

Carboxyl domain

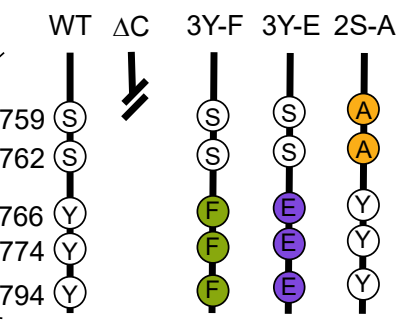

b

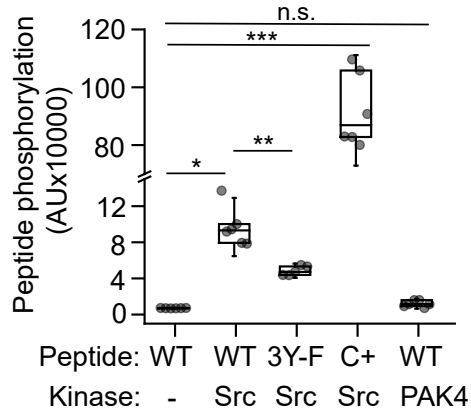

C
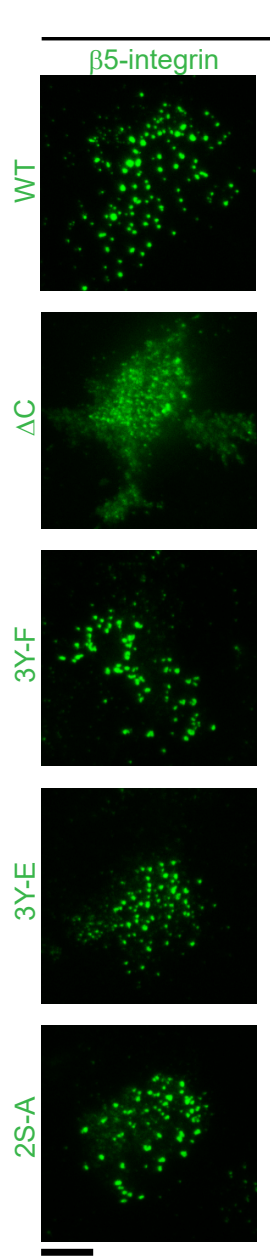

Ctrl
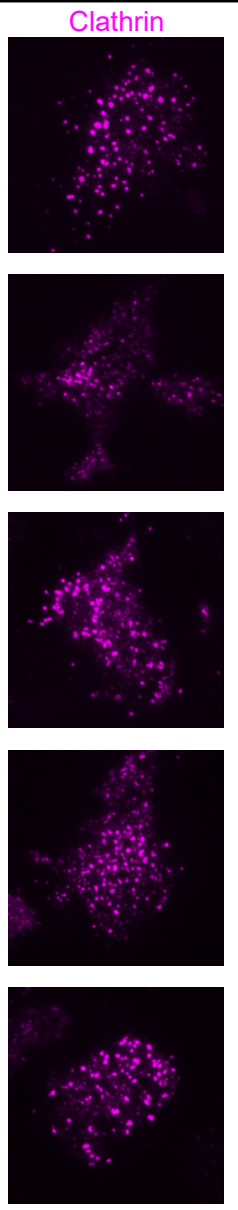

d
EGF
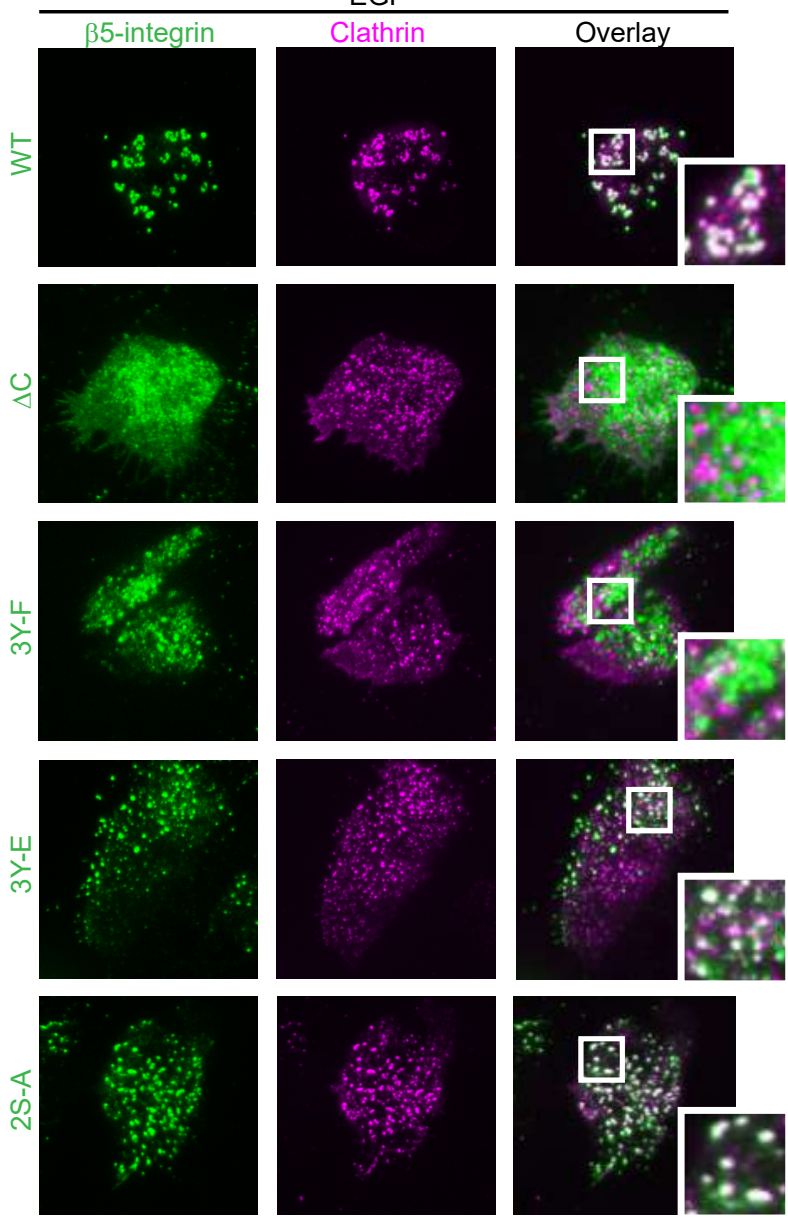

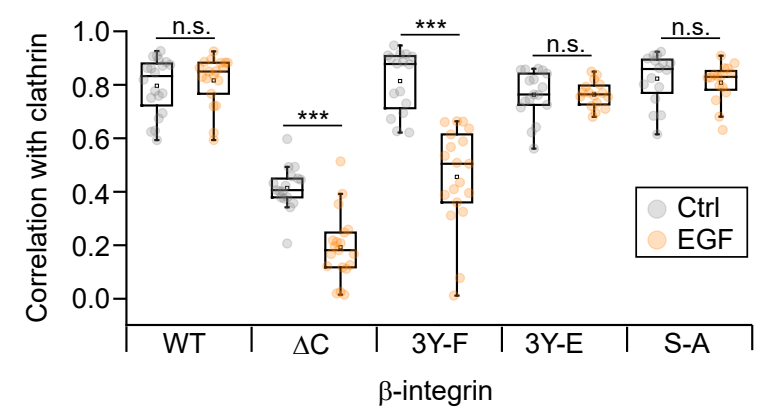


Fig. 5

a
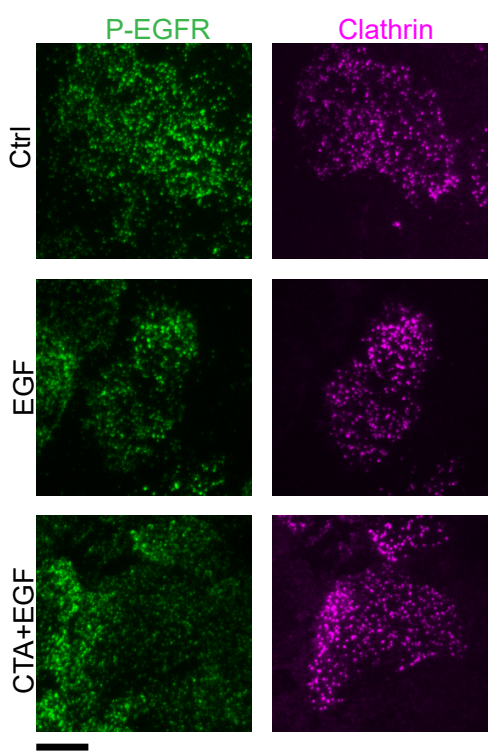

e
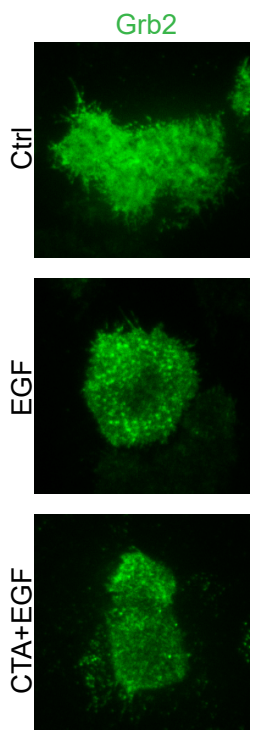

Clathrin
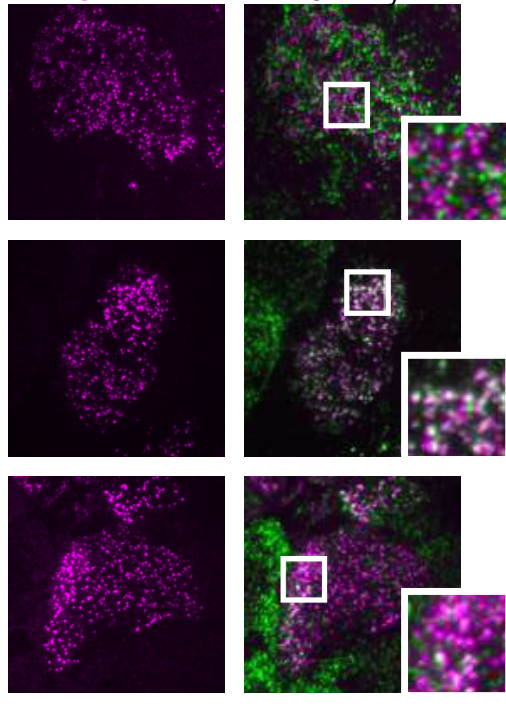

Clathrin
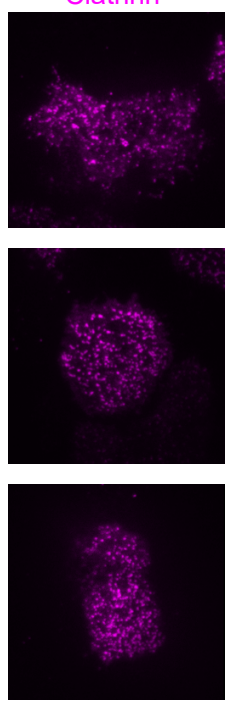

Overlay
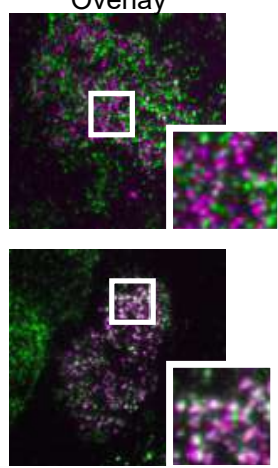

Overlay
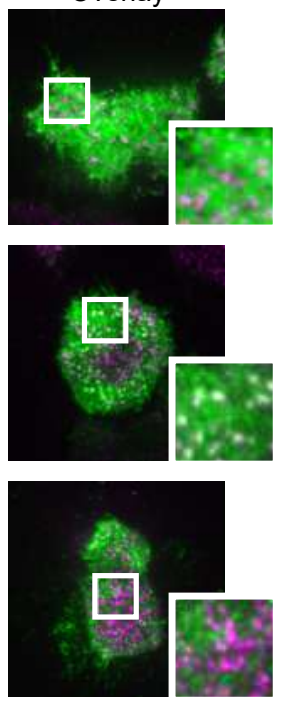

b
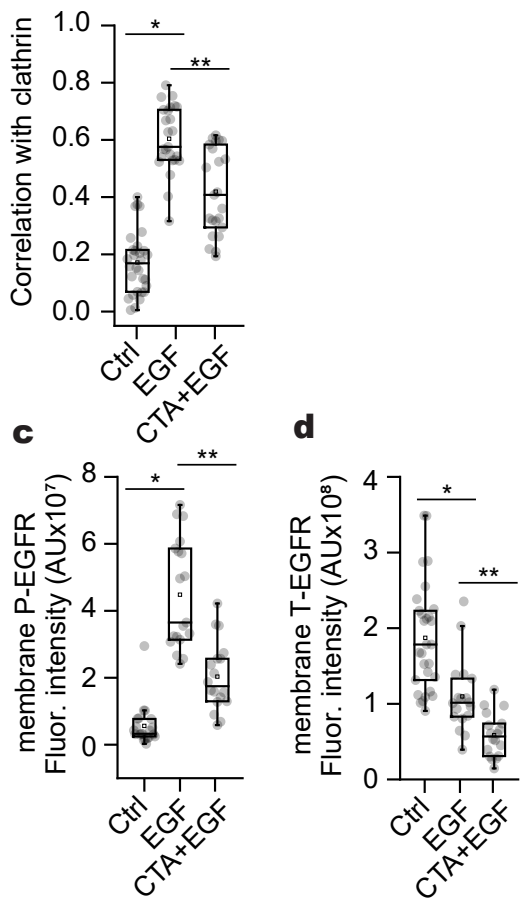

g
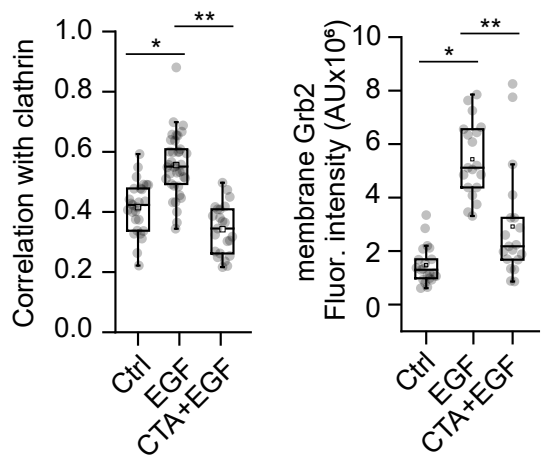
bioRxiv preprint doi: https://doi.org/10.1101/2020.11.09.373837; this version posted November 9, 2020. The copyright holder for this preprint (which was not certified by peer review) is the author/funder, who has granted bioRxiv a license to display the preprint in perpetuity. It is made available under aCC-BY-NC 4.0 International license.

Fig. 6

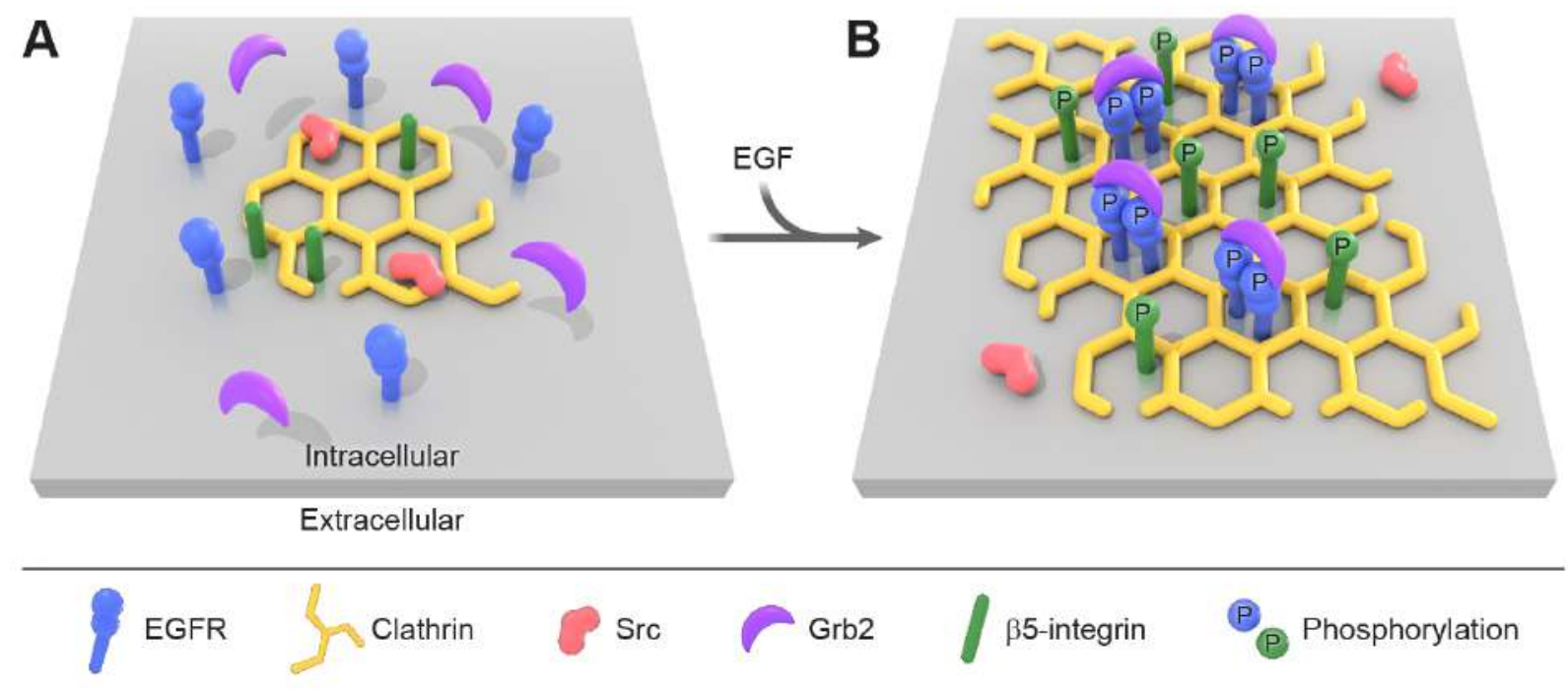


bioRxiv preprint doi: https://doi.org/10.1101/2020.11.09.373837; this version posted November 9, 2020. The copyright holder for this preprint (which was not certified by peer review) is the author/funder, who has granted bioRxiv a license to display the preprint in perpetuity. It is made available under aCC-BY-NC 4.0 International license.

Sup. Fig. 1

a

Flat

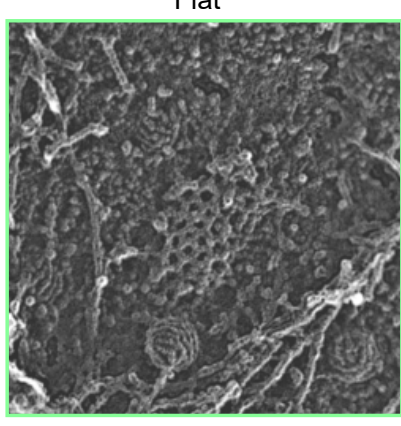

b

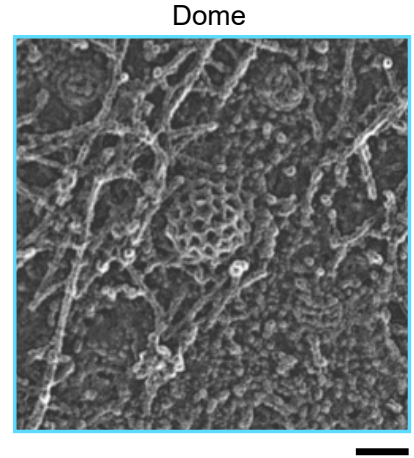

C
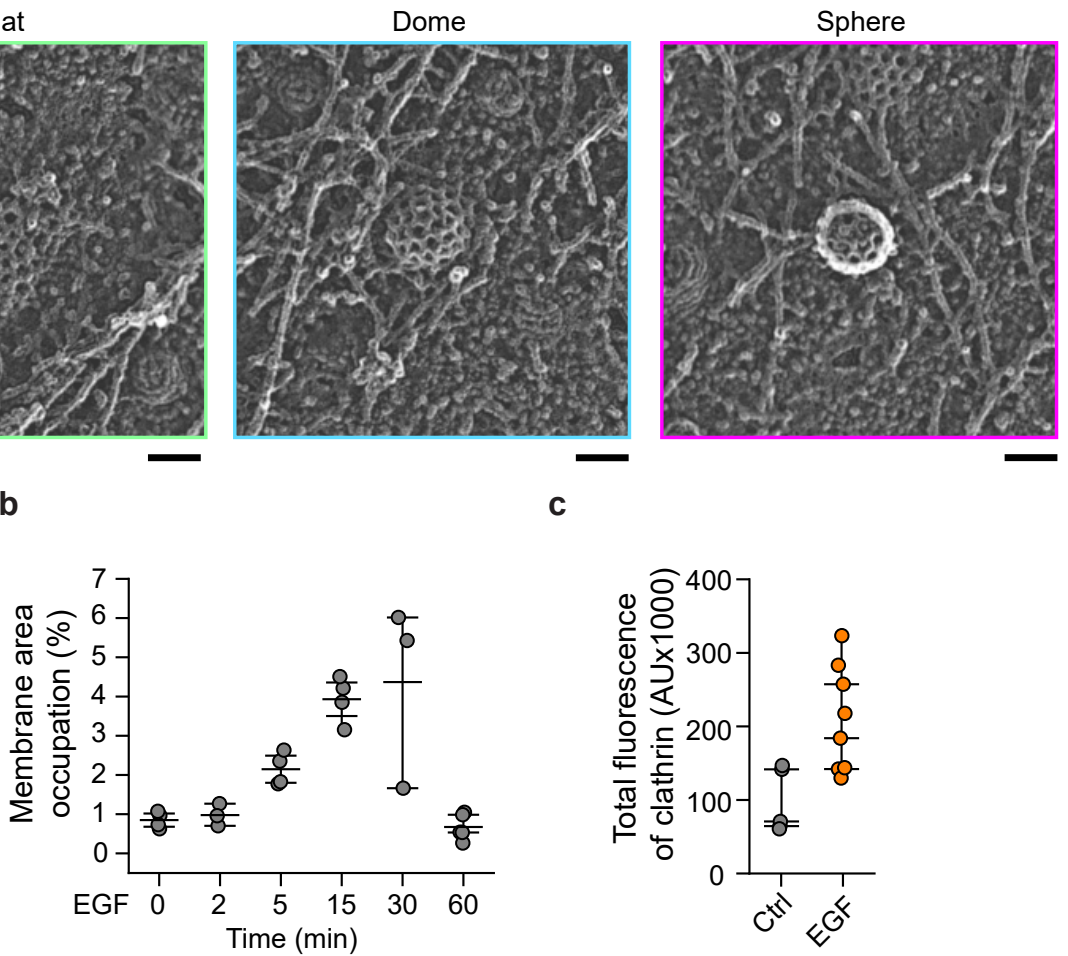
bioRxiv preprint doi: https://doi.org/10.1101/2020.11.09.373837; this version posted November 9, 2020. The copyright holder for this preprint

(which was not certified by peer review) is the author/funder, who has granted bioRxiv a license to display the preprint in perpetuity. It is made available under aCC-BY-NC 4.0 International license.

\section{Sup. Fig. 2}

c

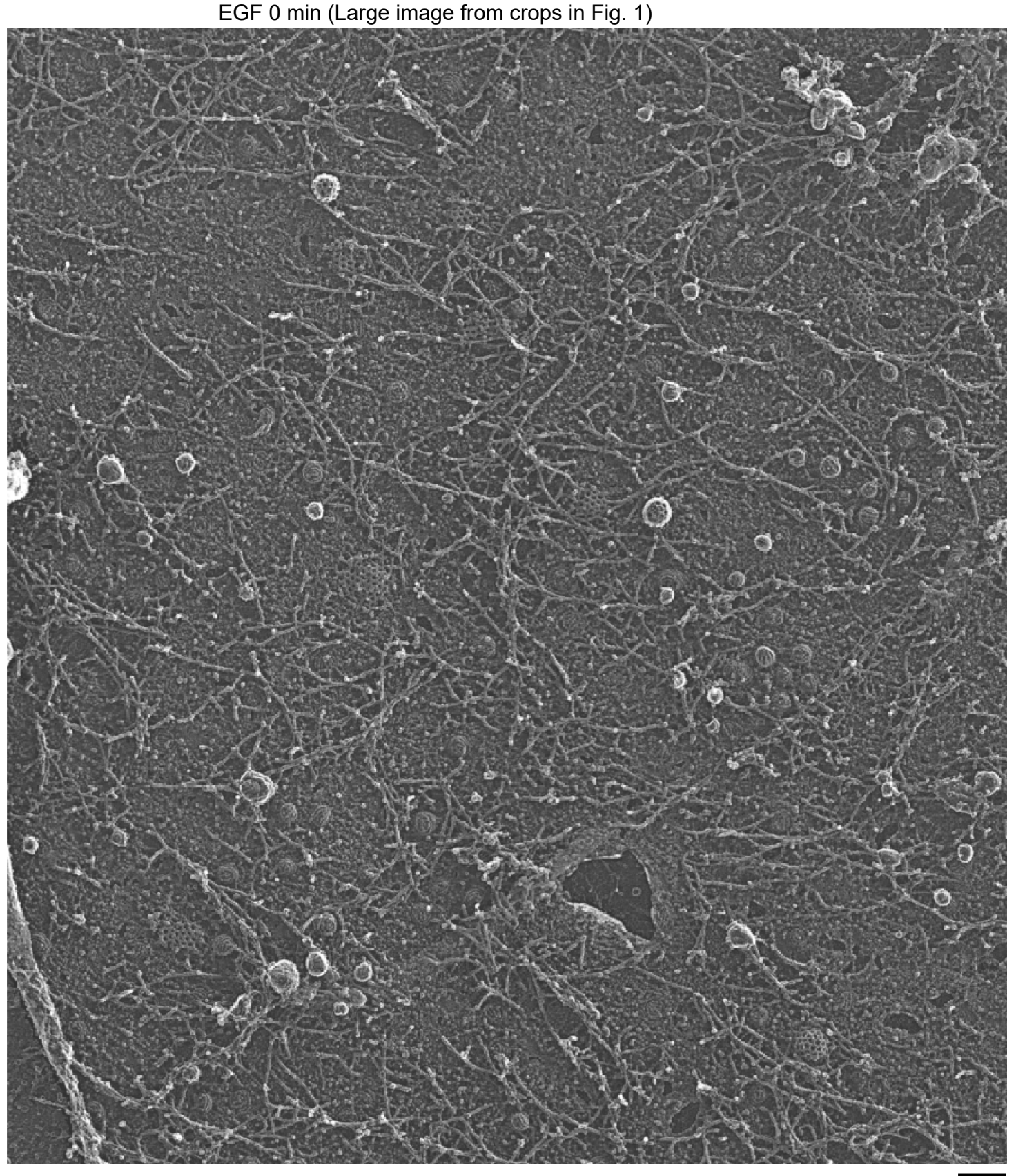


bioRxiv preprint doi: https://doi.org/10.1101/2020.11.09.373837; this version posted November 9,2020. The copyright holder for this preprint

(which was not certified by peer review) is the author/funder, who has granted bioRxiv a license to display the preprint in perpetuity. It is made available under aCC-BY-NC 4.0 International license.

EGF 2 min (Large image from crops in Fig. 1)

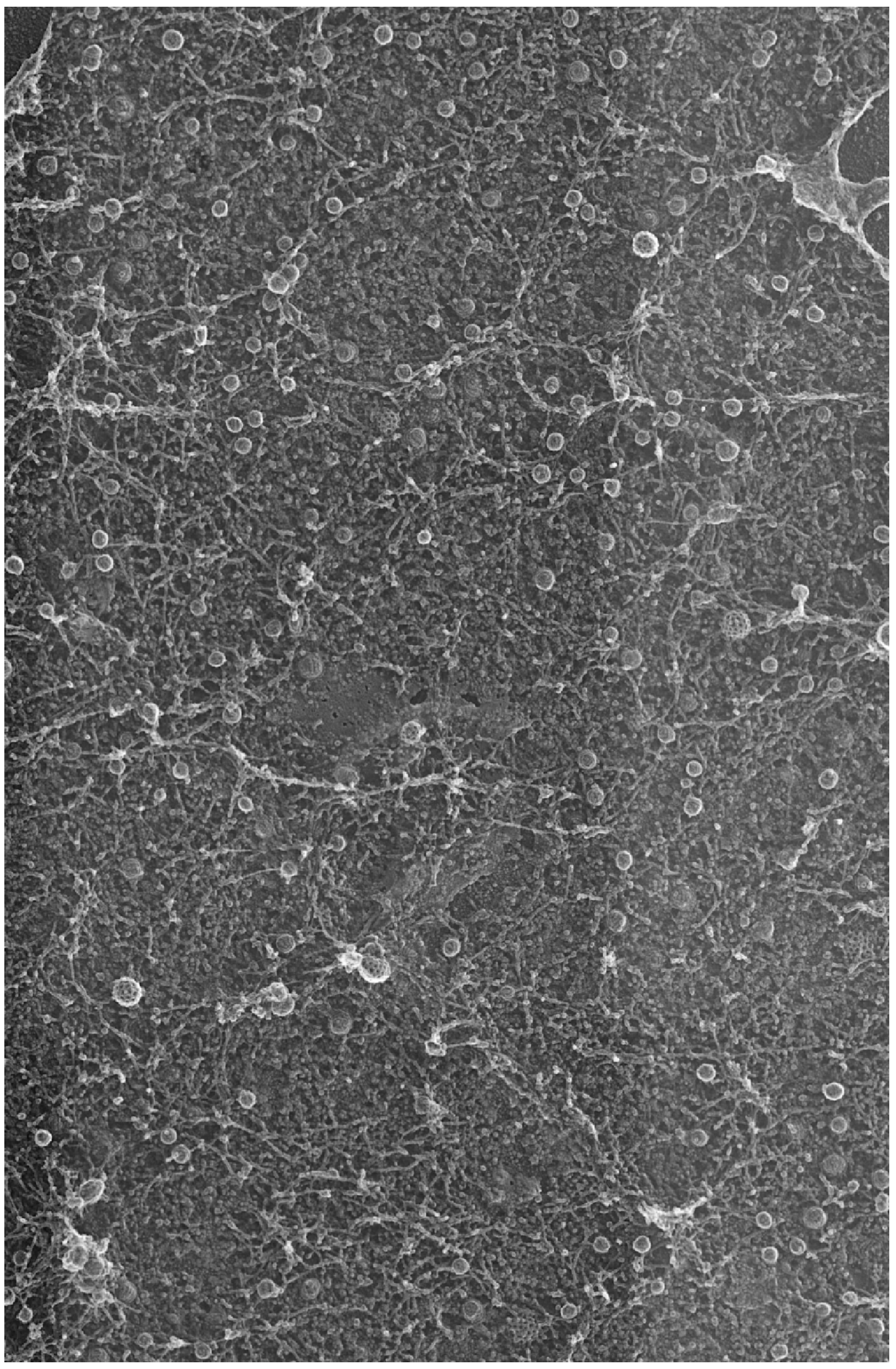


bioRxiv preprint doi: https://doi.org/10.1101/2020.11.09.373837; this version posted November 9, 2020. The copyright holder for this preprint

(which was not certified by peer review) is the author/funder, who has granted bioRxiv a license to display the preprint in perpetuity. It is made available under aCC-BY-NC 4.0 International license.

EGF 5 min (Large image from crops in Fig. 1)

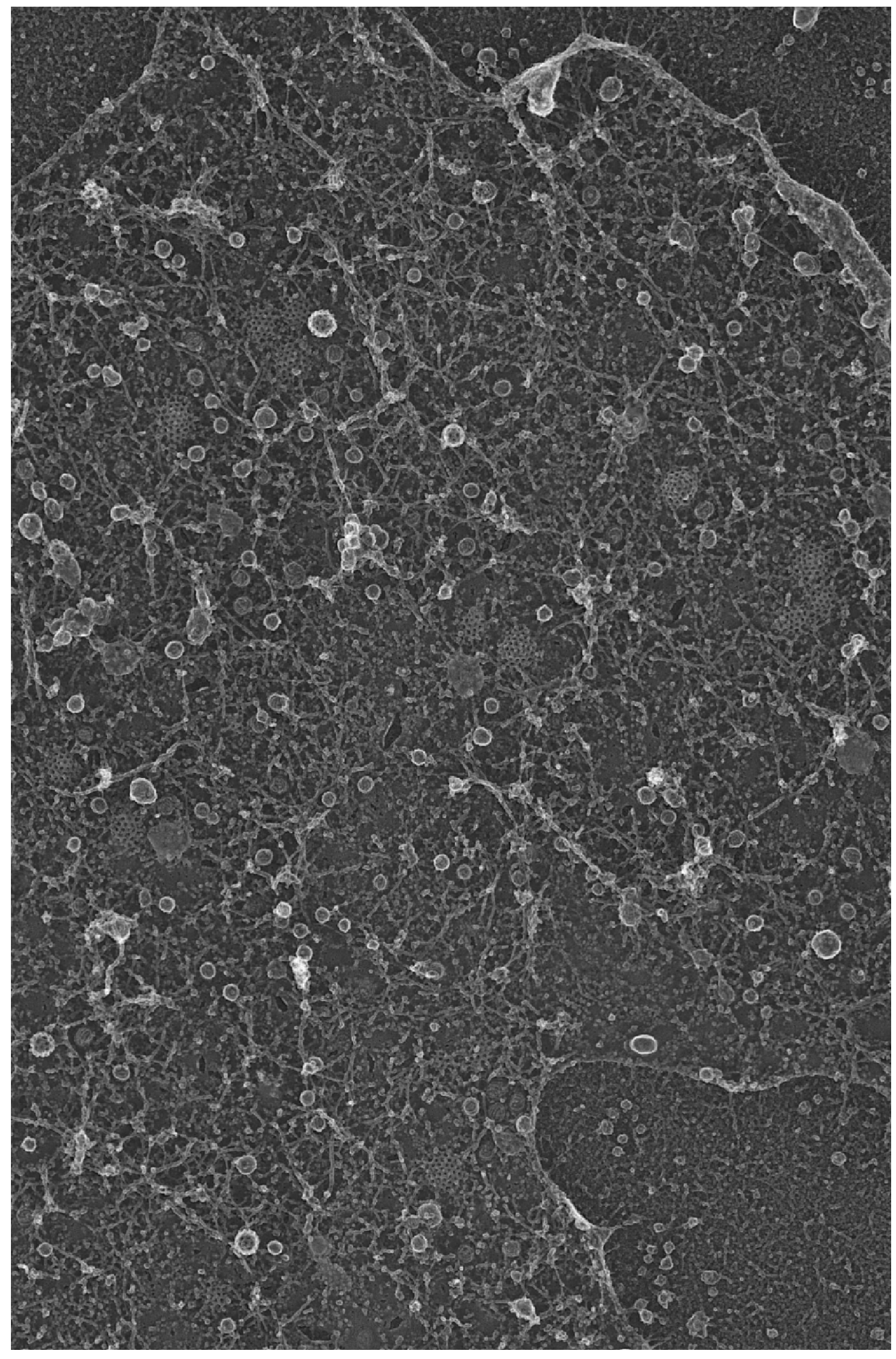


bioRxiv preprint doi: https://doi.org/10.1101/2020.11.09.373837; this version posted November 9, 2020. The copyright holder for this preprint

(which was not certified by peer review) is the author/funder, who has granted bioRxiv a license to display the preprint in perpetuity. It is made available under aCC-BY-NC 4.0 International license.

EGF 15 min (Large image from crops in Fig. 1)

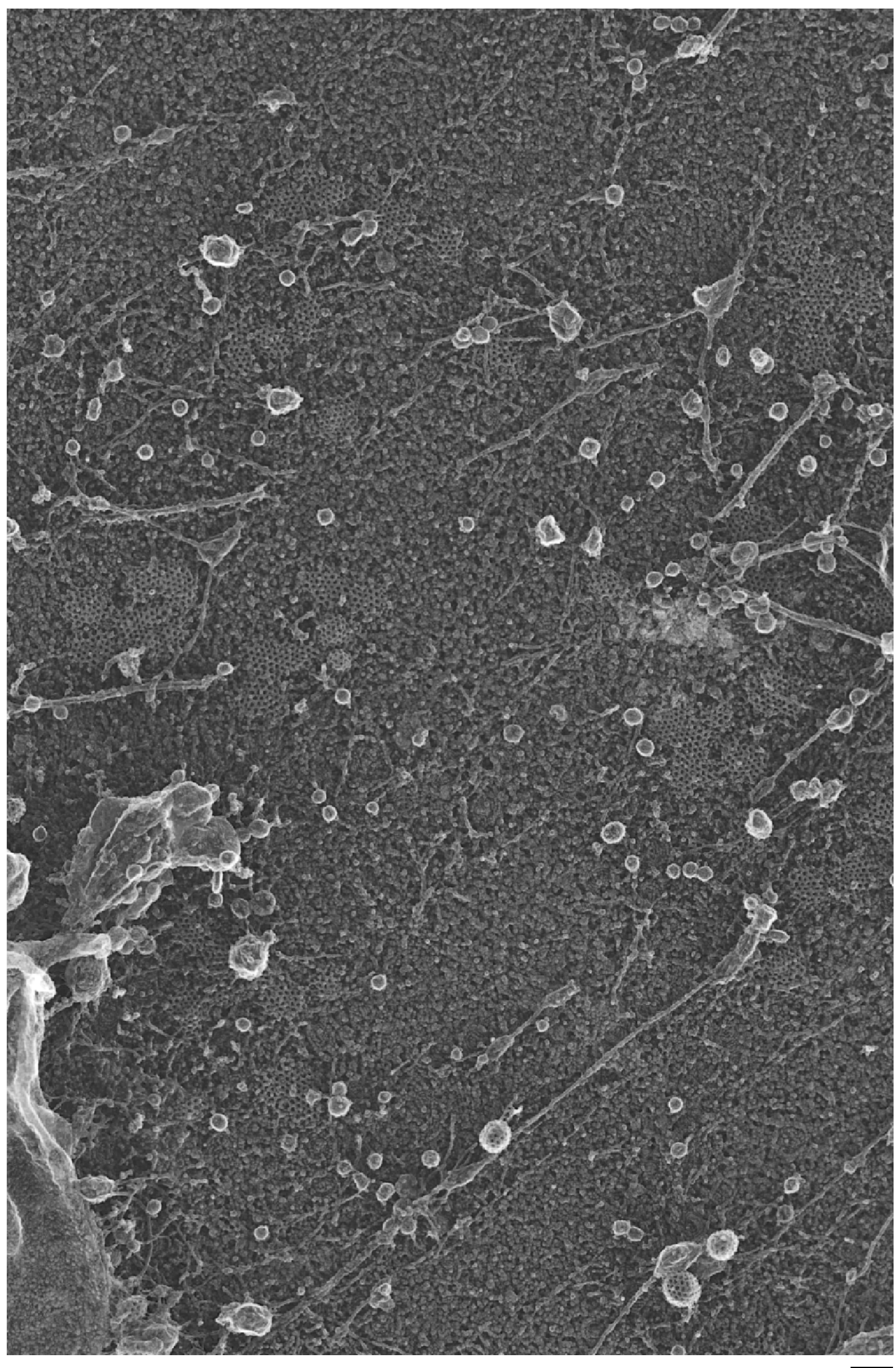


bioRxiv preprint doi: https://doi.org/10.1101/2020.11.09.373837; this version posted November 9, 2020. The copyright holder for this preprint

(which was not certified by peer review) is the author/funder, who has granted bioRxiv a license to display the preprint in perpetuity. It is made available under aCC-BY-NC 4.0 International license.

EGF 30 min (Large image from crops in Fig. 1)

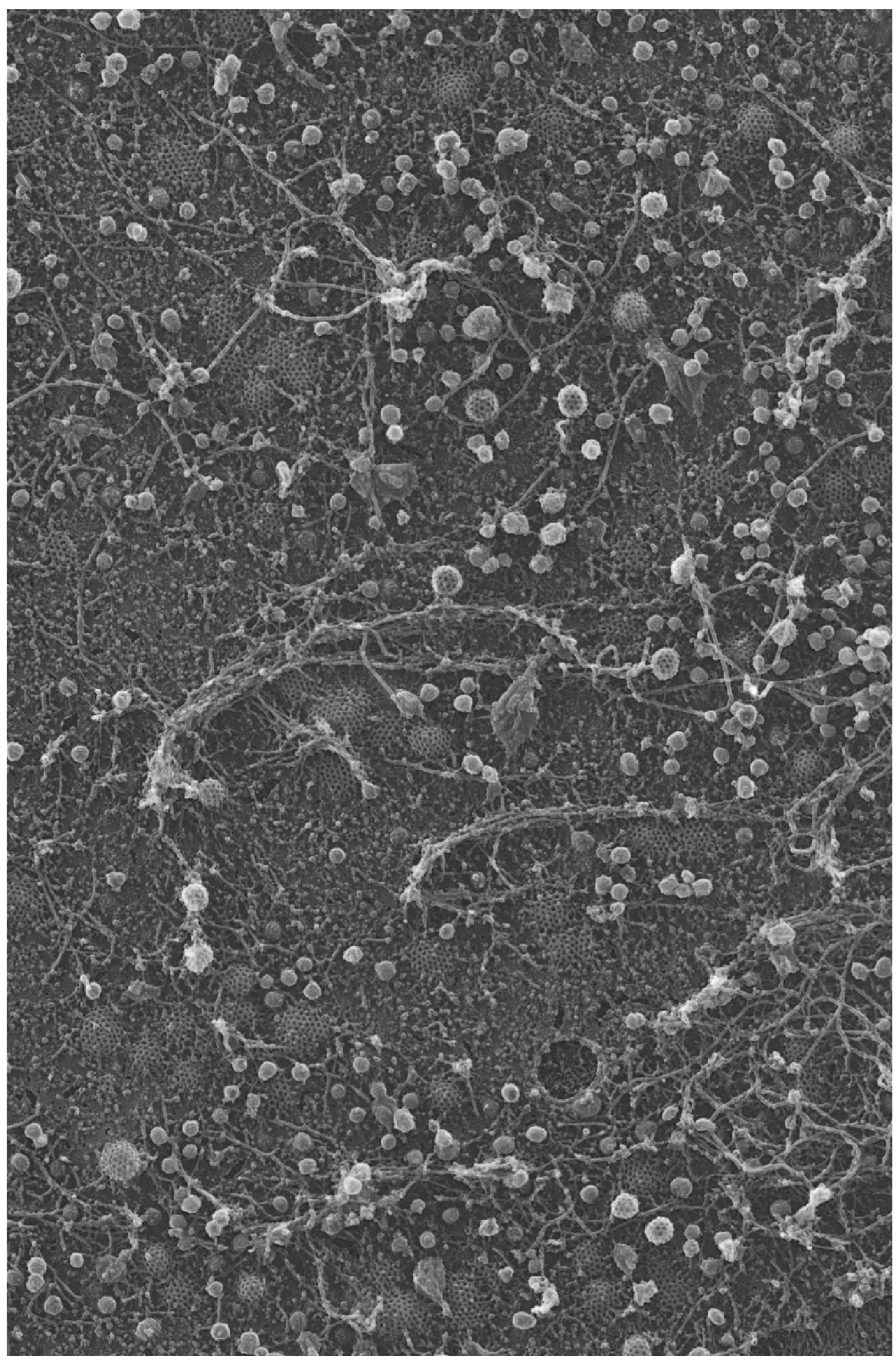


bioRxiv preprint doi: https://doi.org/10.1101/2020.11.09.373837; this version posted November 9,2020. The copyright holder for this preprint

(which was not certified by peer review) is the author/funder, who has granted bioRxiv a license to display the preprint in perpetuity. It is made available under aCC-BY-NC 4.0 International license.

EGF 60 min (Large image from crops in Fig. 1)

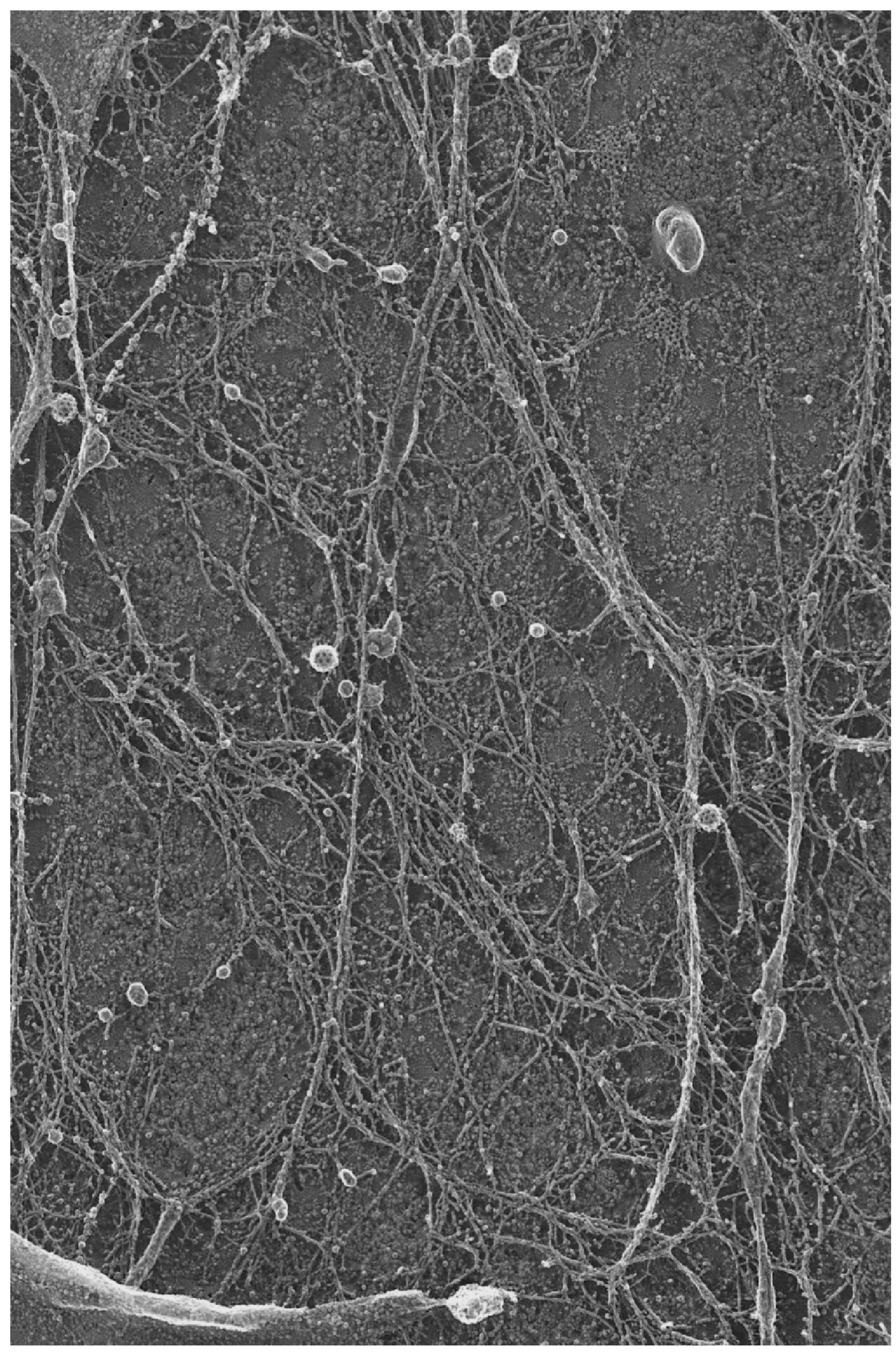


bioRxiv preprint doi: https://doi.org/10.1101/2020.11.09.373837; this version posted November 9, 2020. The copyright holder for this preprint (which was not certified by peer review) is the author/funder, who has granted bioRxiv a license to display the preprint in perpetuity. It is made available under aCC-BY-NC 4.0 International license.

\section{Sup. Fig. 3}

a

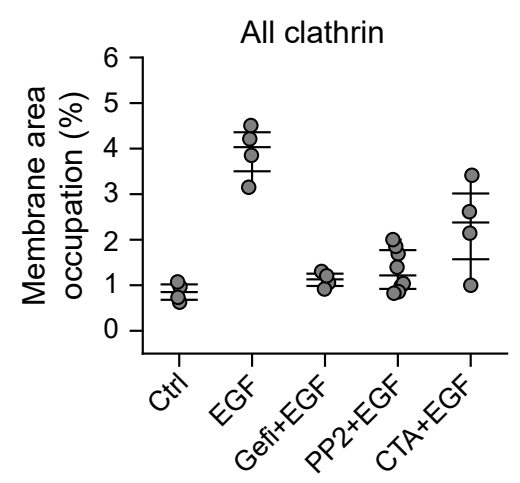

f

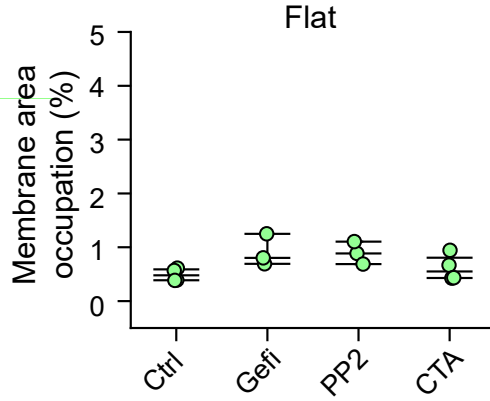

i

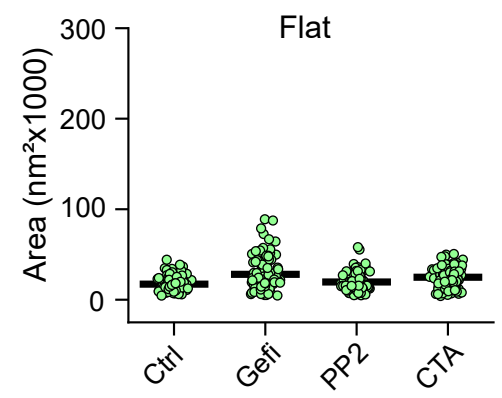

b

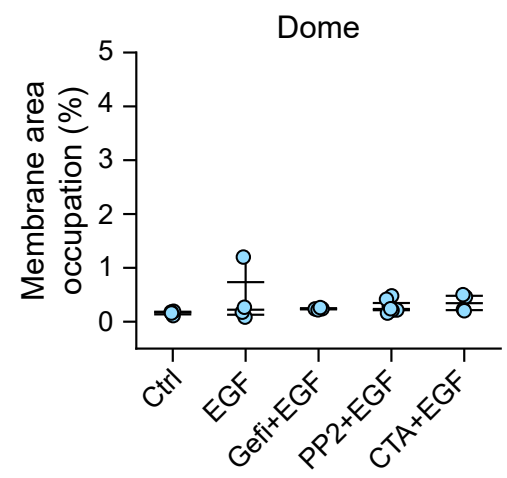

d

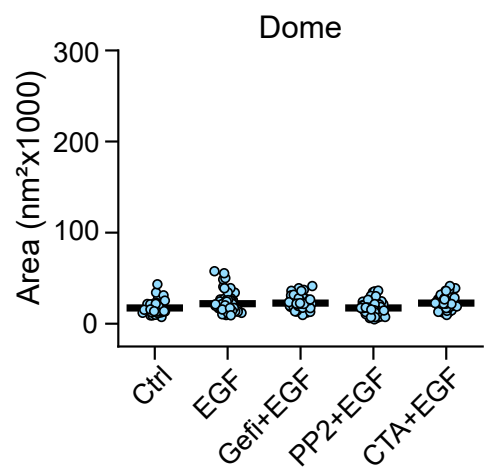

g

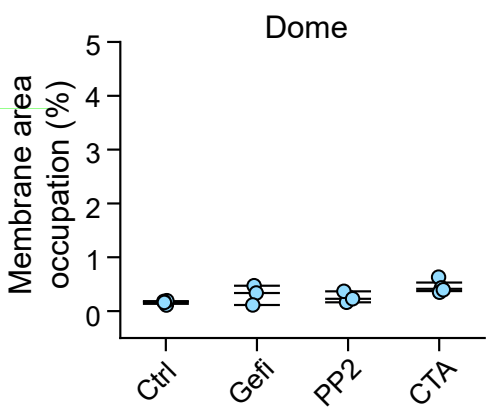

j

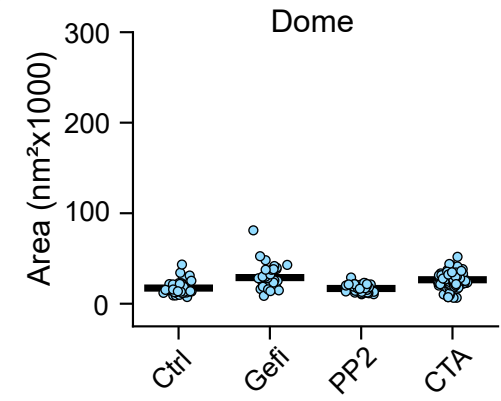

C

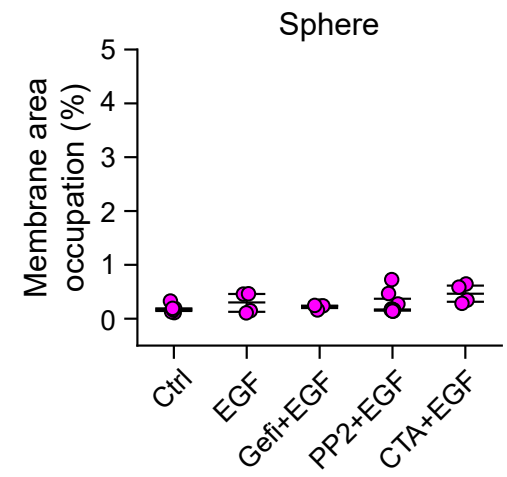

e

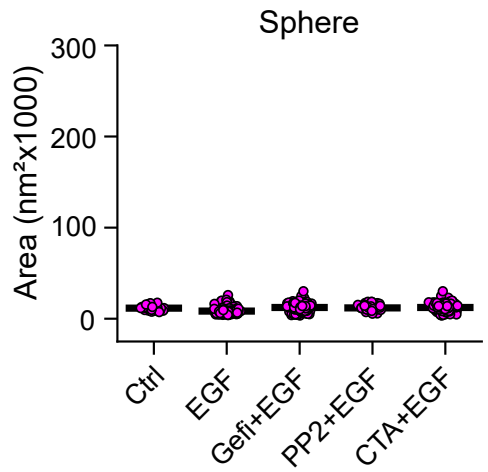

h

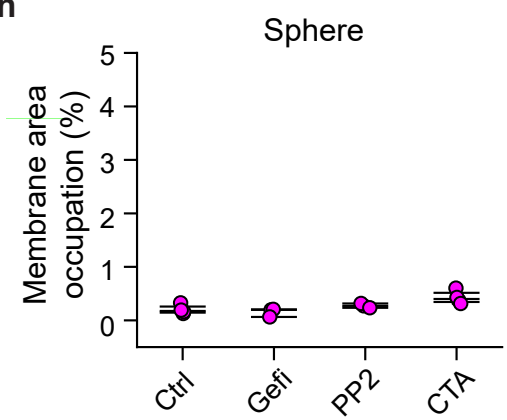

k

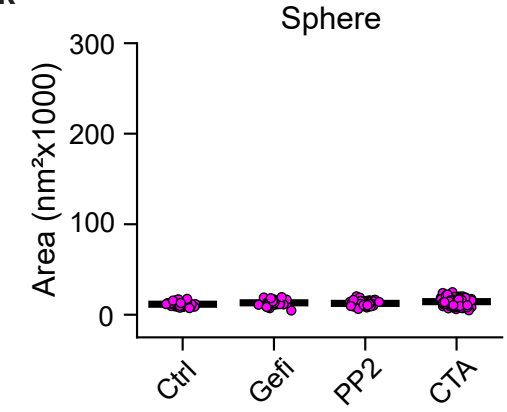

$$
\text { I }
$$

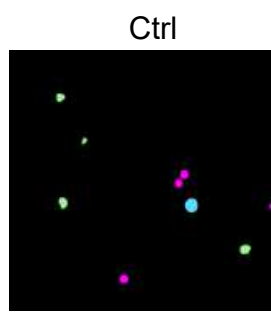

Gefi

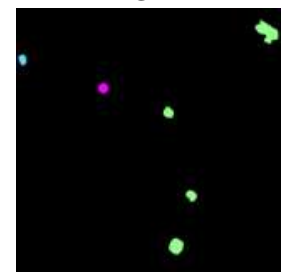

PP2

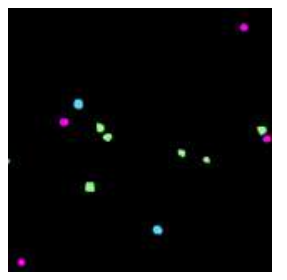

CTA

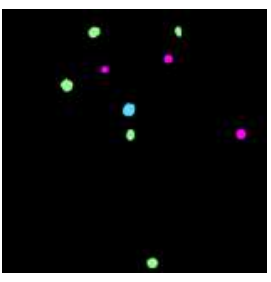


bioRxiv preprint doi: https://doi.org/10.1101/2020.11.09.373837; this version posted November 9, 2020. The copyright holder for this preprint

(which was not certified by peer review) is the author/funder, who has granted bioRxiv a license to display the preprint in perpetuity. It is made

\section{Sup. Fig. 4} available under aCC-BY-NC 4.0 International license.

Ctrl (Large image from crops in Fig. 2)

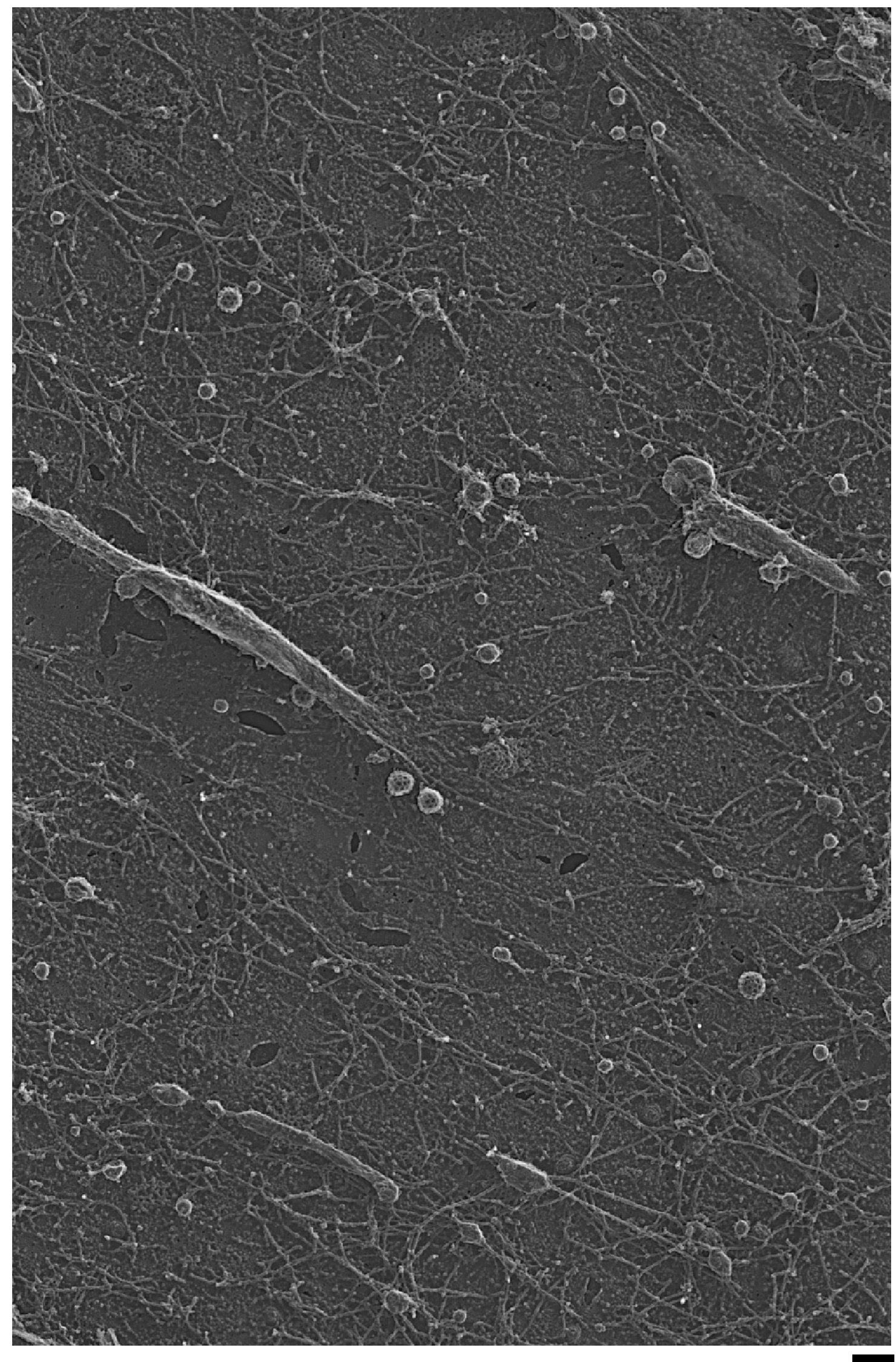


bioRxiv preprint doi: https://doi.org/10.1101/2020.11.09.373837; this version posted November 9, 2020. The copyright holder for this preprint

(which was not certified by peer review) is the author/funder, who has granted bioRxiv a license to display the preprint in perpetuity. It is made available under aCC-BY-NC 4.0 International license.

EGF (Large image from crops in Fig. 2)

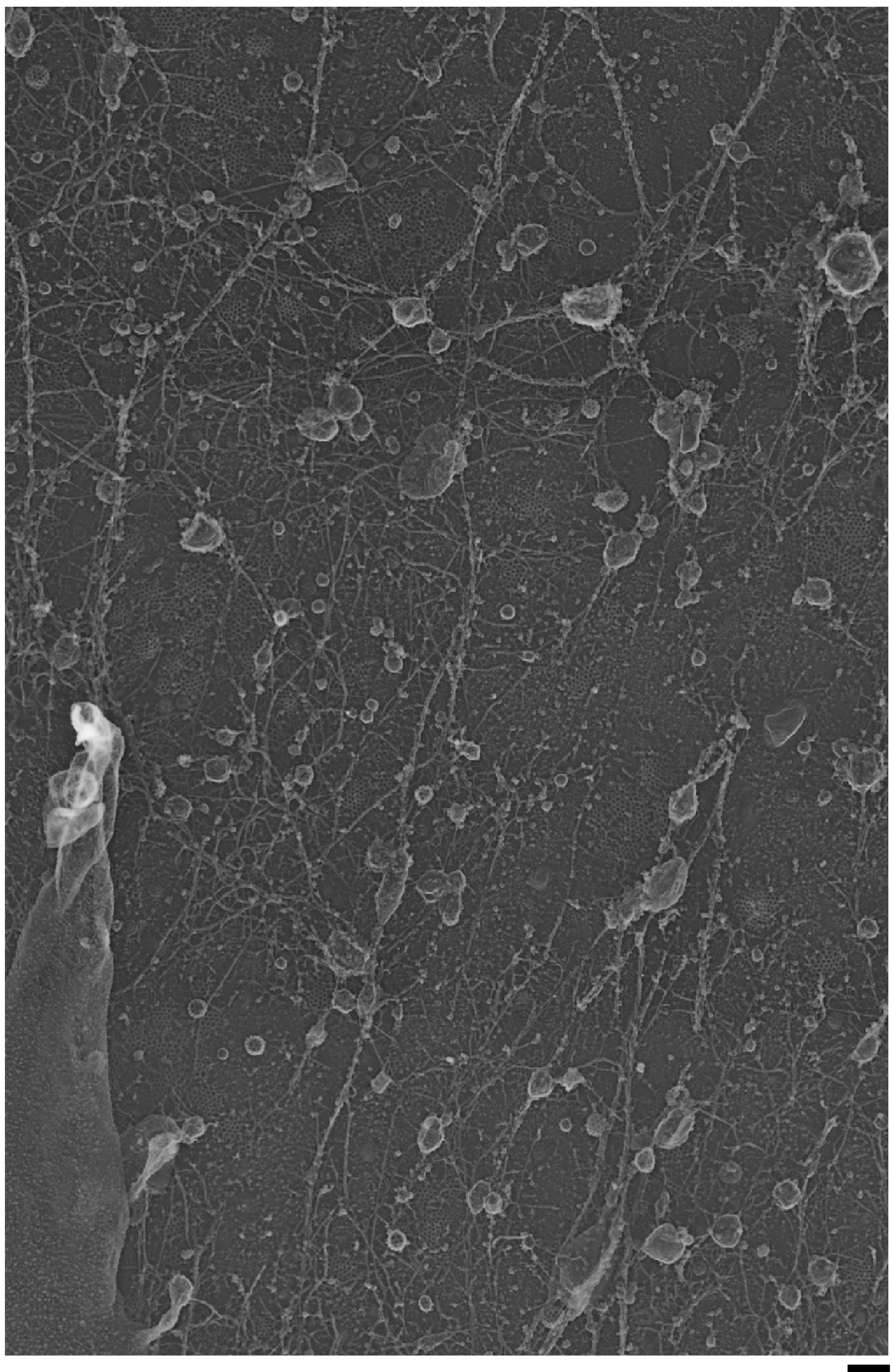


bioRxiv preprint doi: https://doi.org/10.1101/2020.11.09.373837; this version posted November 9, 2020. The copyright holder for this preprint

(which was not certified by peer review) is the author/funder, who has granted bioRxiv a license to display the preprint in perpetuity. It is made available under aCC-BY-NC 4.0 International license.

Gefi+EGF (Large image from crops in Fig. 2)

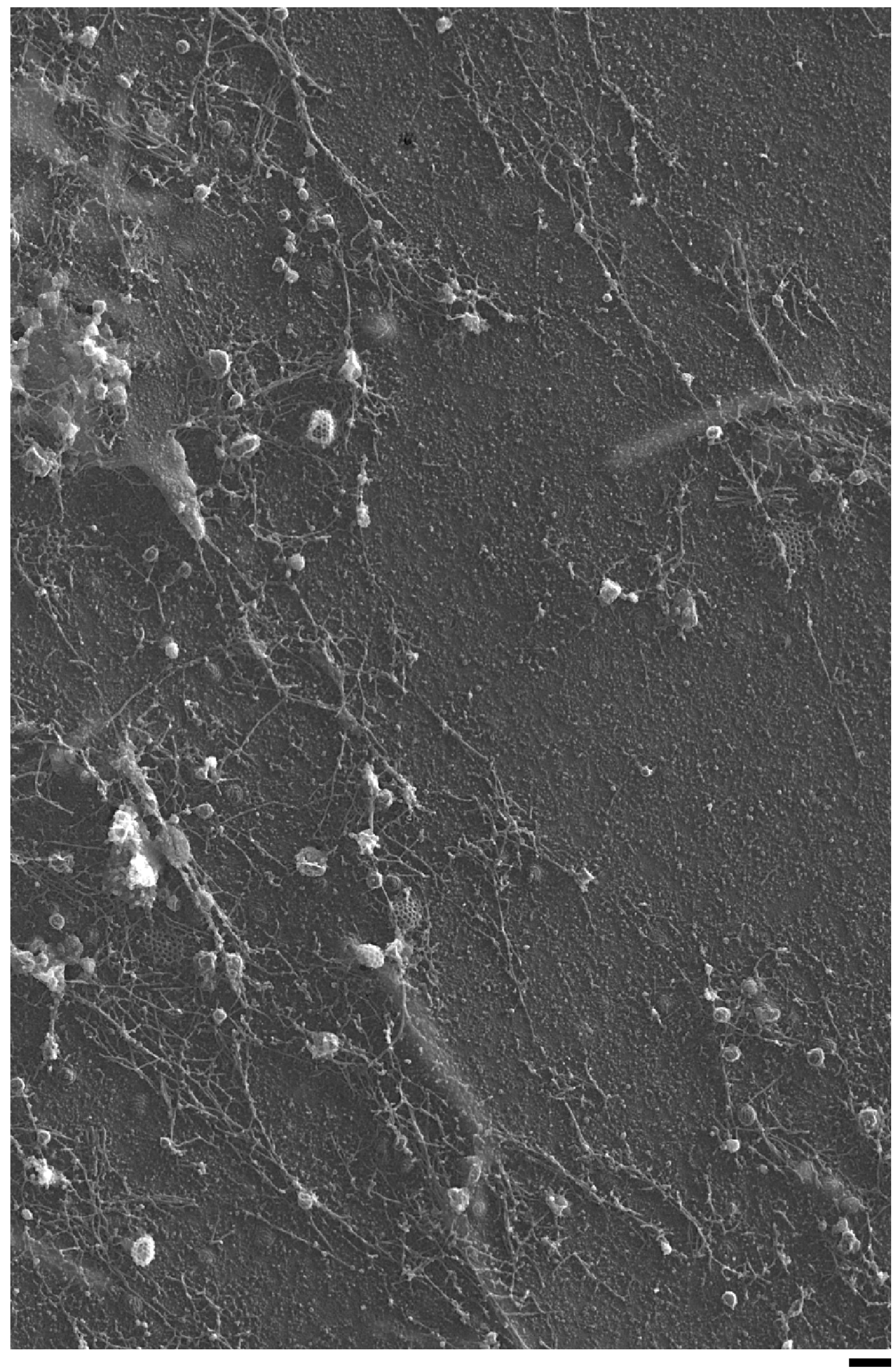


bioRxiv preprint doi: https://doi.org/10.1101/2020.11.09.373837; this version posted November 9, 2020. The copyright holder for this preprint (which was not certified by peer review) is the author/funder, who has granted bioRxiv a license to display the preprint in perpetuity. It is made available under aCC-BY-NC 4.0 International license.

PP2+EGF (Large image from crops in Fig. 2)

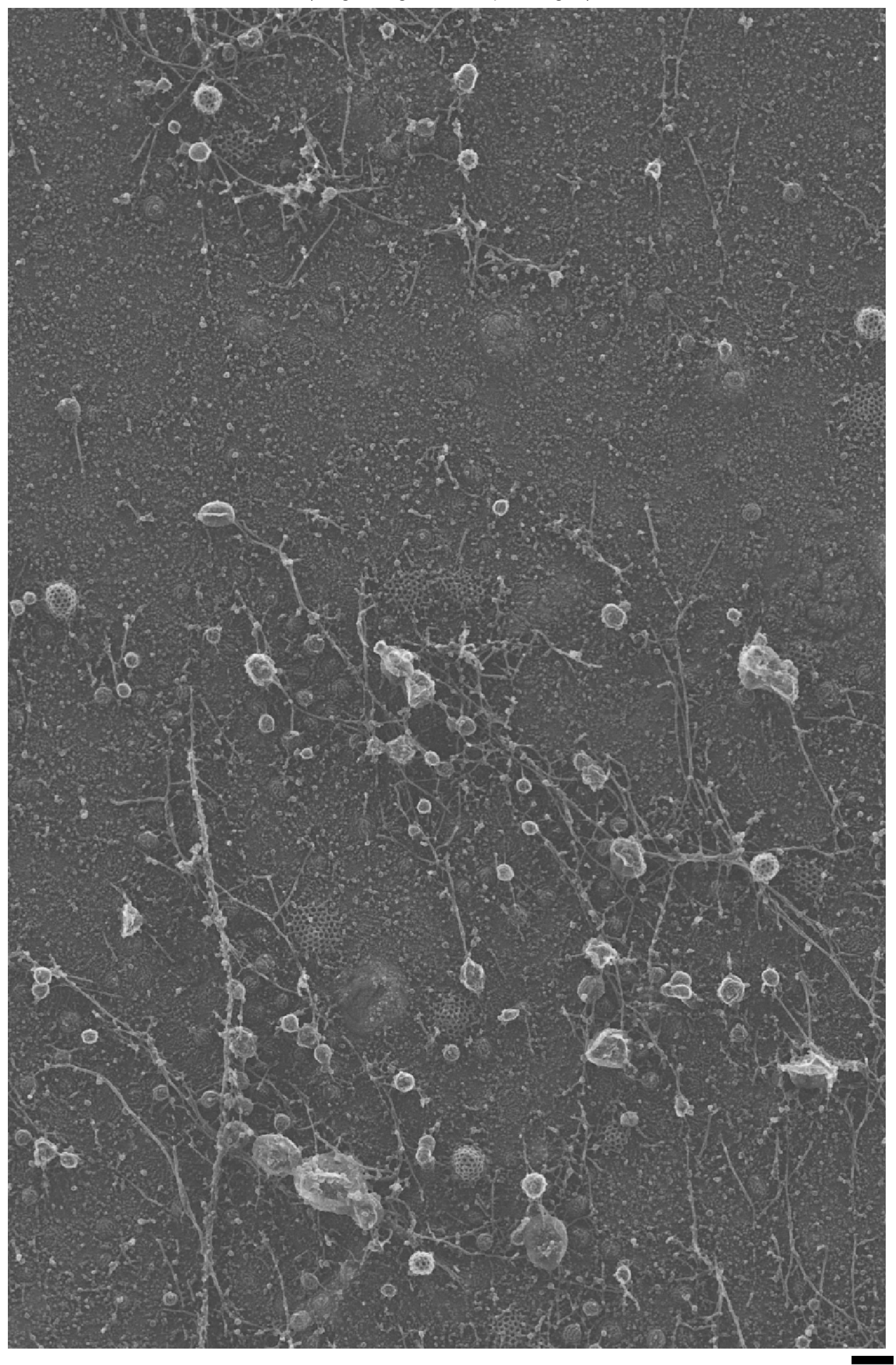


bioRxiv preprint doi: https://doi.org/10.1101/2020.11.09.373837; this version posted November 9, 2020. The copyright holder for this preprint

(which was not certified by peer review) is the author/funder, who has granted bioRxiv a license to display the preprint in perpetuity. It is made available under aCC-BY-NC 4.0 International license.

CTA+EGF (Large image from crops in Fig. 2)

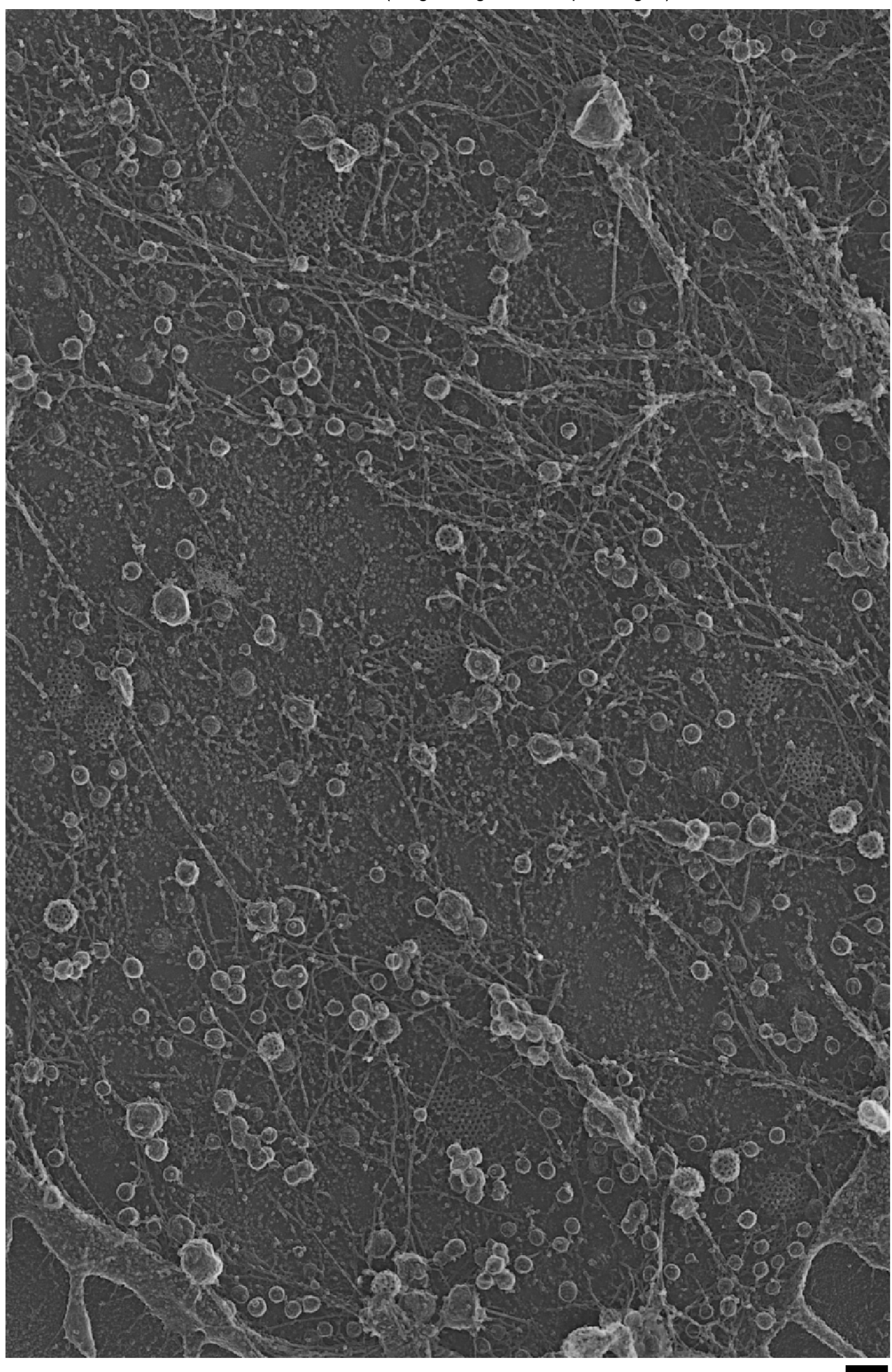


bioRxiv preprint doi: https://doi.org/10.1101/2020.11.09.373837; this version posted November 9, 2020. The copyright holder for this preprint (which was not certified by peer review) is the author/funder, who has granted bioRxiv a license to display the preprint in perpetuity. It is made available under aCC-BY-NC 4.0 International license.

Gefi (Large image from crops in Fig. 2)

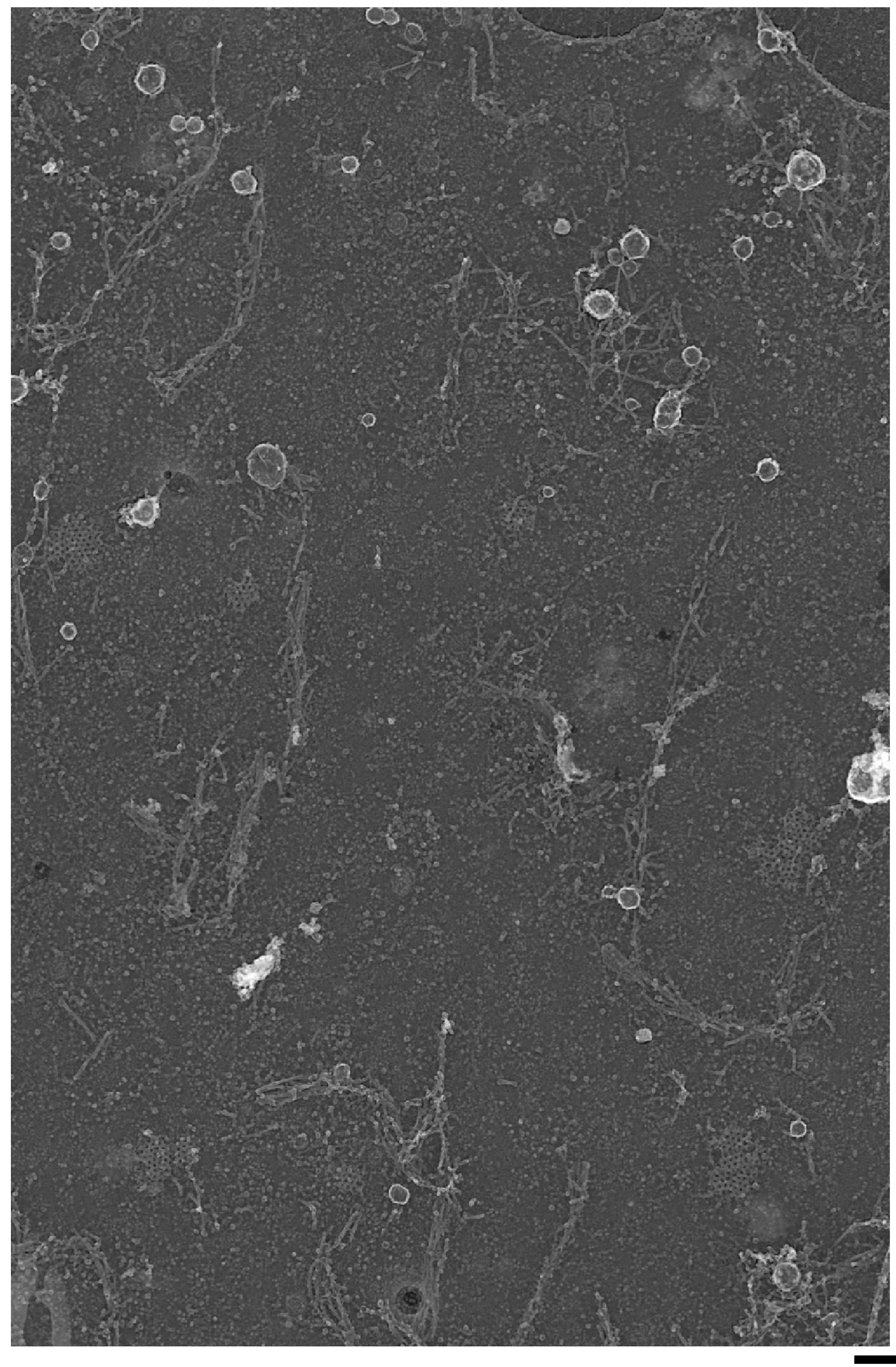



available under aCC-BY-NC 4.0 International license.

PP2 (Large image from crops in Fig. 2)

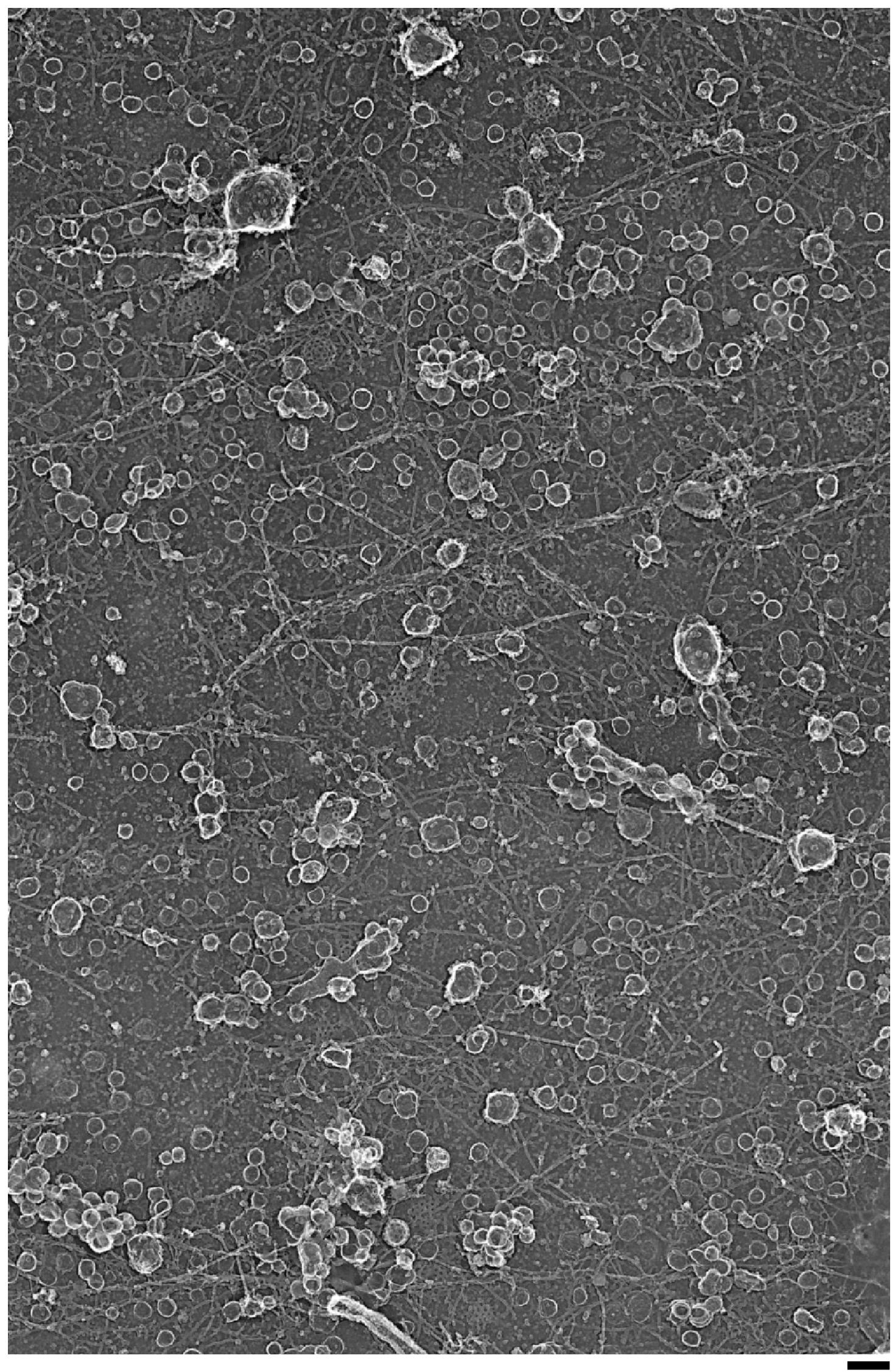


bioRxiv preprint doi: https://doi.org/10.1101/2020.11.09.373837; this version posted November 9, 2020. The copyright holder for this preprint

(which was not certified by peer review) is the author/funder, who has granted bioRxiv a license to display the preprint in perpetuity. It is made available under aCC-BY-NC 4.0 International license.

PP2 (Large image from crops in Fig. 2)

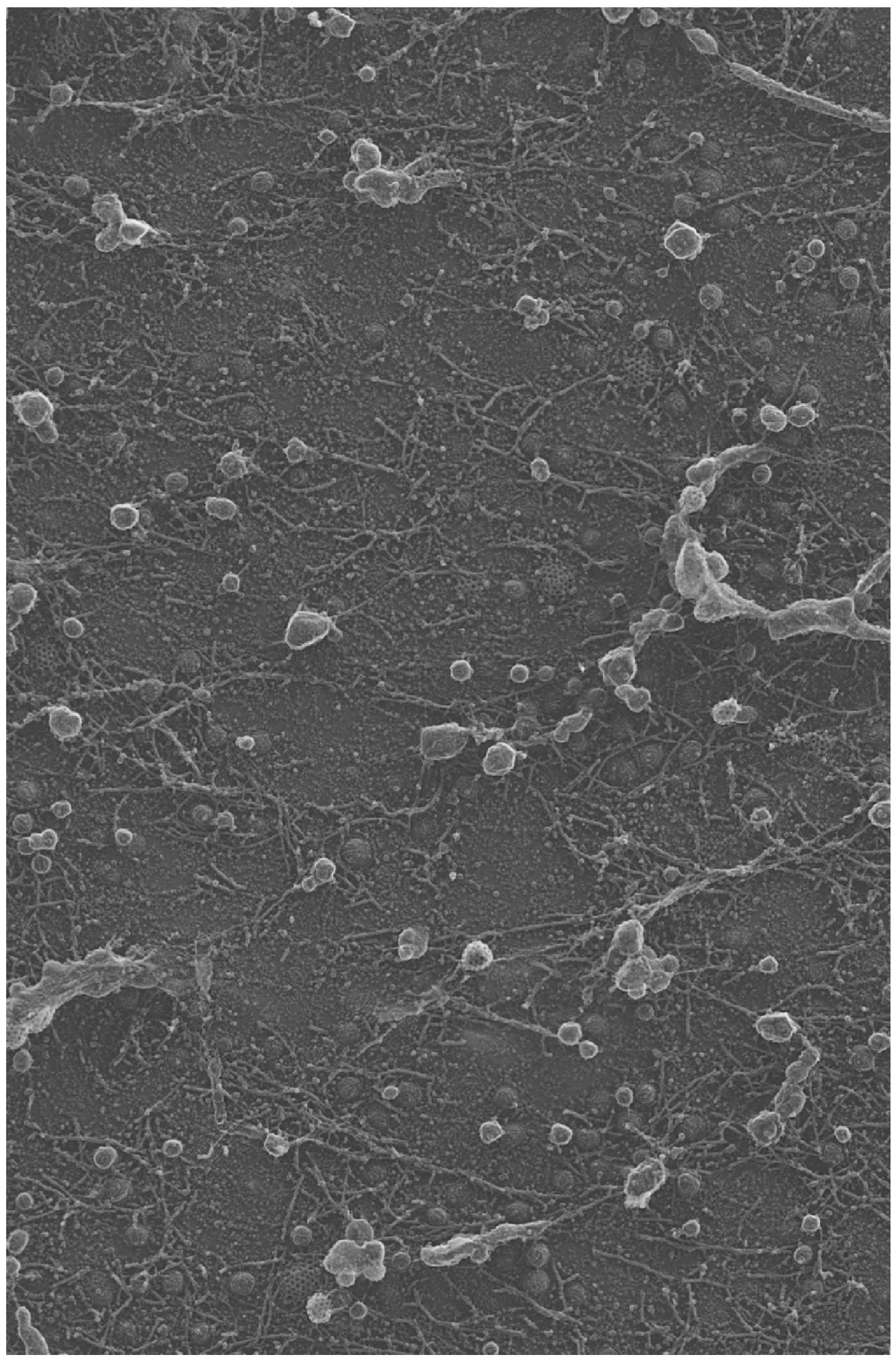


bioRxiv preprint doi: https://doi.org/10.1101/2020.11.09.373837; this version posted November 9, 2020. The copyright holder for this preprint (which was not certified by peer review) is the author/funder, who has granted bioRxiv a license to display the preprint in perpetuity. It is made Sup. Fig. 5 available under aCC-BY-NC 4.0 International license.

a
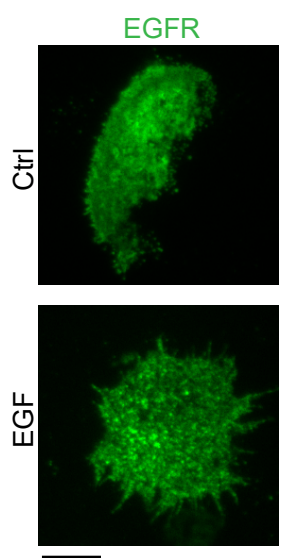

Clathrin
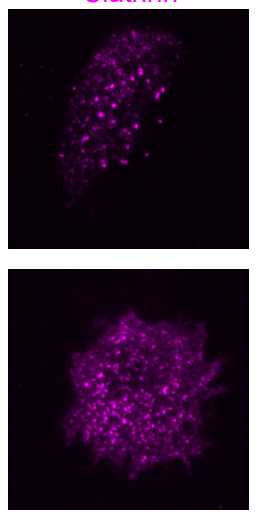

Overlay
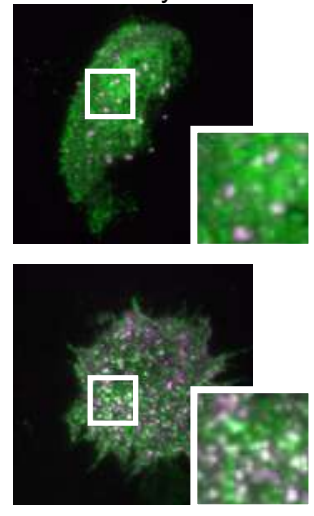

b

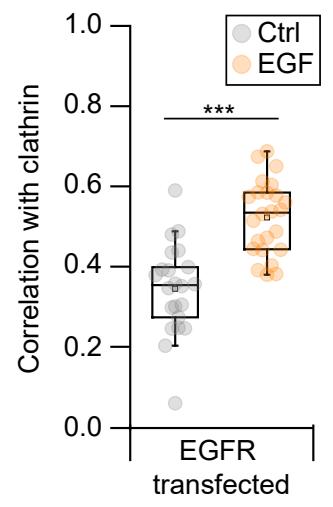

Sup. Fig. 6

a
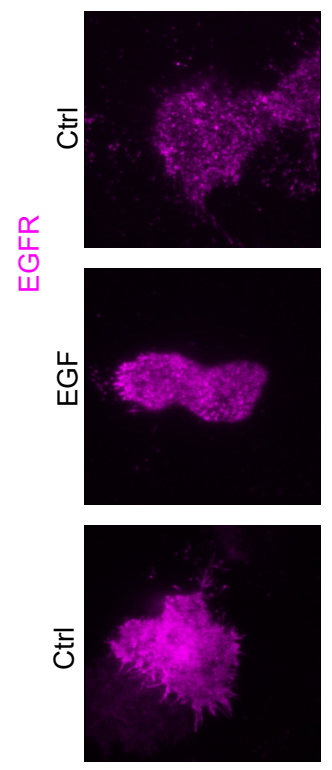

บำ

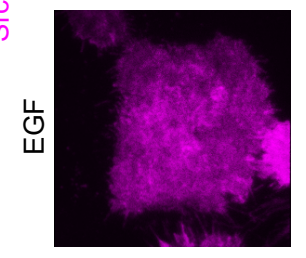

$\beta 5$-integrin
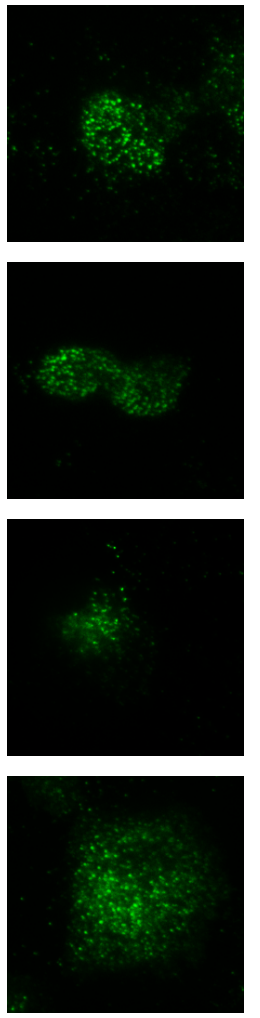

Overlay
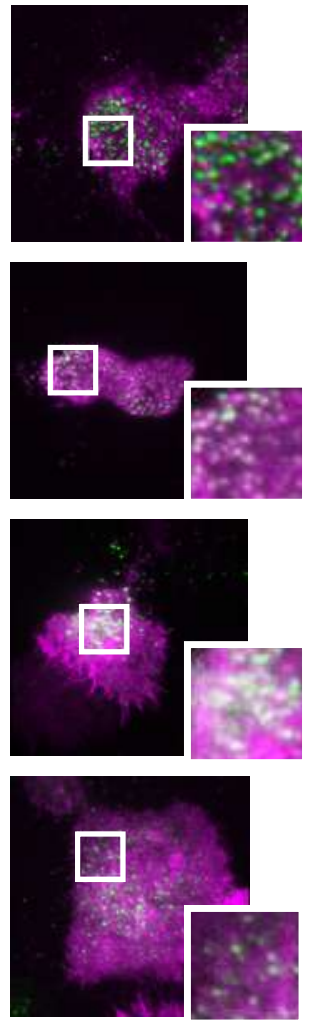

b

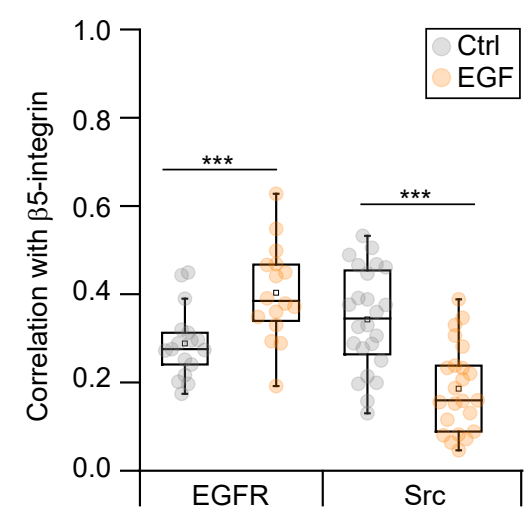

Sup. Fig. 7

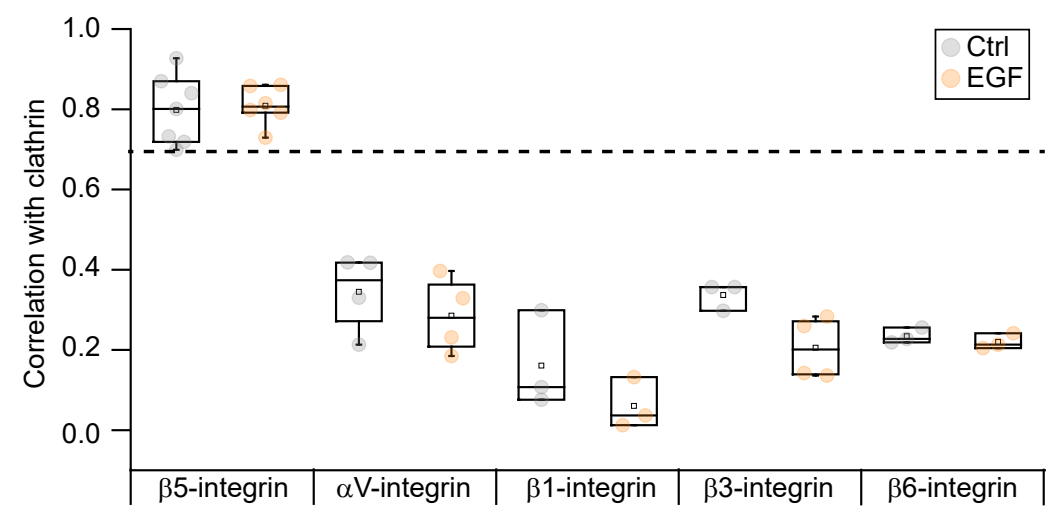


bioRxiv preprint doi: https://doi.org/10.1101/2020.11.09.373837; this version posted November 9, 2020. The copyright holder for this preprint (which was not certified by peer review) is the author/funder, who has granted bioRxiv a license to display the preprint in perpetuity. It is made available under aCC-BY-NC 4.0 International license.

\section{Sup. Fig. 8}

a

H_sapiens

M-musculus

$\mathrm{B}^{-}$taurus

P_cynocephalus

$\mathrm{X}$-laevis

D_rerio $\beta 5$-integrin cytoplasmic domain

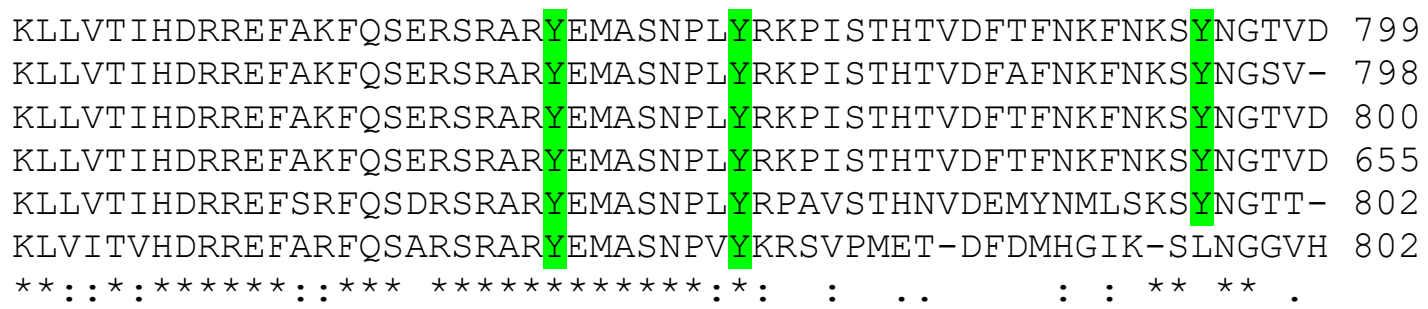

b
ITGB5
ITGB1
ITGB2
ITGB3
ITGB 6
ITGB 7

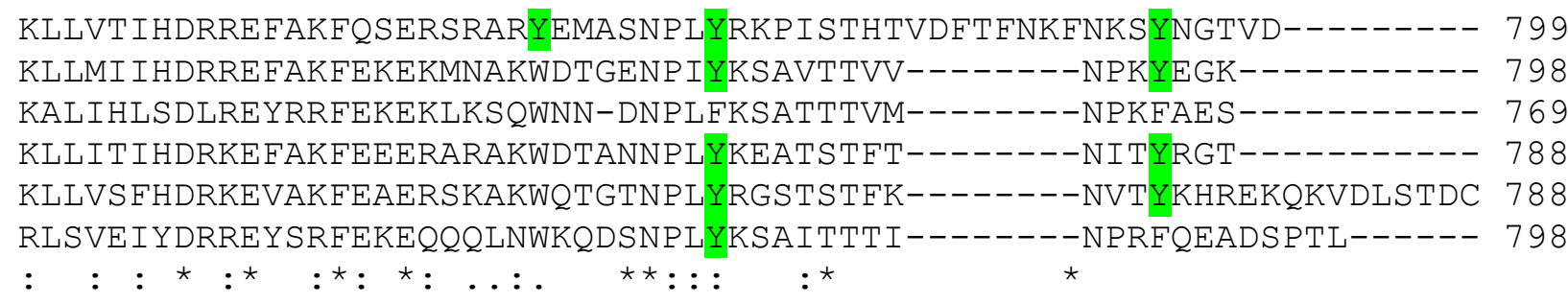

$\beta$-integrin cytoplasmic domain

\begin{tabular}{|c|c|l|l|}
\hline Position & Residue & \multicolumn{1}{|c|}{ Peptide } & \multicolumn{1}{c|}{ Predicted Kinases } \\
\hline 766 & $\mathrm{Y}$ & SERSRARYEMASNPL & Src, InsR, EGFR \\
\hline 774 & $\mathrm{Y}$ & EMASNPLYRKPISTH & Src, InsR, EGFR,Abl2, Itk, Ptk6 \\
\hline 794 & $\mathrm{Y}$ & FNKFNKSYNGTVD & Src, InsR, EGFR, PDGFRa, Fes, Syk, Ptk6 \\
\hline
\end{tabular}

d

\begin{tabular}{|l|l|l|l|l|}
\hline & & Y766 & Y774 & Y794 \\
\hline \multirow{2}{*}{$\therefore$} & GPS 5.0 & & & \\
\cline { 2 - 5 } & Netphos 3.0 & & & \\
\cline { 2 - 5 } & PhosphoSitePlus & & & \\
\hline
\end{tabular}

